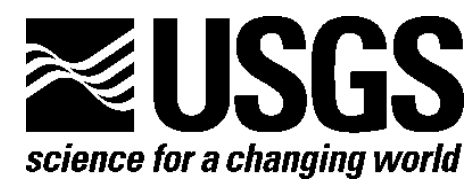

Ecosystem Health in Mineralized Terrane-Data from Podiform Chromite (Chinese Camp Mining District, California), Quartz Alunite (Castle Peak and Masonic Mining Districts, Nevada/California), and Mo/Cu Porphyry (Battle Mountain Mining District, Nevada) Deposits

By Steve W. Blecker, Lisa L. Stillings, Michael C. Amacher, James A. Ippolito, and Nicole M. Decrappeo

Open-File Report 2010-1040

U.S. Department of the Interior

U.S. Geological Survey 


\section{U.S. Department of the Interior \\ KEN SALAZAR, Secretary}

\section{U.S. Geological Survey \\ Marcia K. McNutt, Director}

U.S. Geological Survey, Reston, Virginia: 2010

For product and ordering information:

World Wide Web: http://www.usgs.gov/pubprod/

Telephone: 1-888-ASK-USGS

For more information on the USGS-the Federal source for science about the Earth,

its natural and living resources, natural hazards, and the environment:

World Wide Web: http://www.usgs.gov/

Telephone: 1-888-ASK-USGS

Suggested citation:

Blecker, S.W., Stillings, L.L., Amacher, M.C., Ippolito, J.A., and DeCrappeo, N.M. 2010, Ecosystem health in mineralized terrane; data from podiform chromite (Chinese Camp mining district, California), quartz alunite (Castle Peak and Masonic mining districts, Nevada/California), and Mo/Cu porphyry (Battle Mountain mining district, Nevada) deposits. U.S. Geological Survey Open-File Report 2010-1040, 38 p. and data tables [http://pubs.usgs.gov/of/2010/1040/].

Any use of trade, product, or firm names is for descriptive purposes only and does not imply endorsement by the U.S. Government.

Although this report is in the public domain, permission must be secured from the individual copyright owners to reproduce any copyrighted material contained within this report. 


\section{Contents}

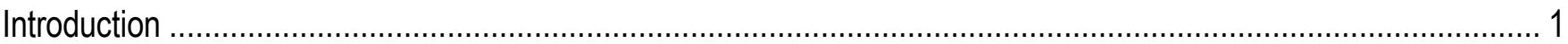

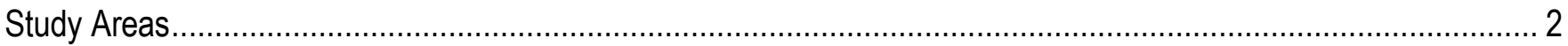

Red Hills, Bureau of Land Management Area of Critical Concern (near Sonora, California)........................ 2

Castle Peak (near Reno, Nevada) and Masonic Mining district (near Bridgeport, California) ....................... 3

Buckingham (near Battle Mountain, Nevada) .............................................................................. 4

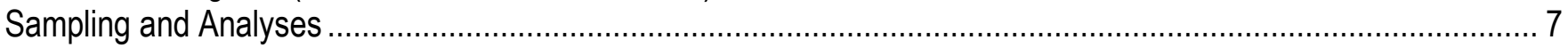

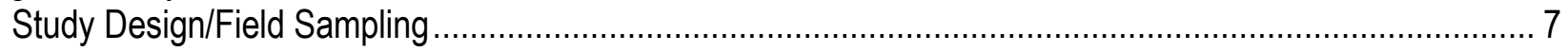

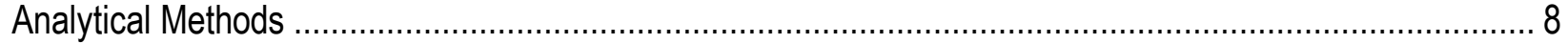

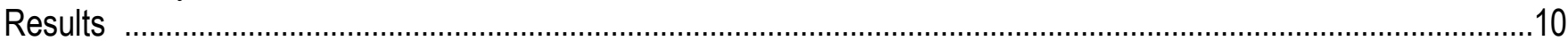

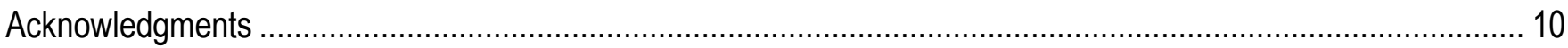

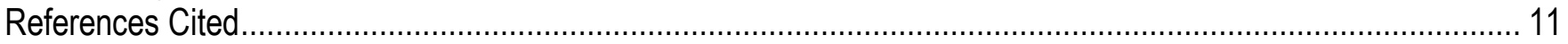

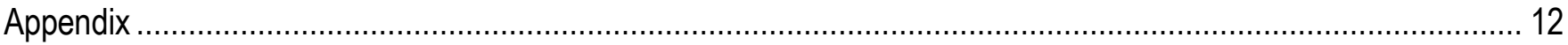

\section{Figures}

Figure 1. Red Hills (podiform chromite) study area location map. ………....................................................... 3

Figure 2. Castle Peak and Masonic (quartz-alunite) study area location maps. .................................................. 4

Figure 3. Buckingham (Mo/Cu porphyry) study area location map ................................................................... 5

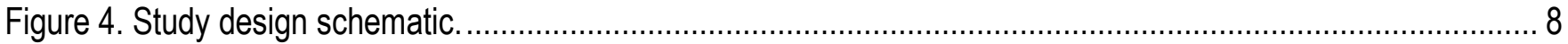

Figure 5. Red Hills: Soil microbial data (Enzyme activity), across the study-design levels ................................. 13

Figure 6. Red Hills: Soil microbial data (Mineralizable C and N, Organic C, Total N) across the study-design

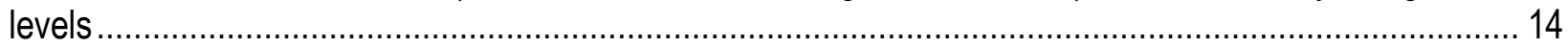

Figure 7. Red Hills: Soil microbial data (Ecoplate AWCD, Microbial biomass (PLFA)) across the study-design

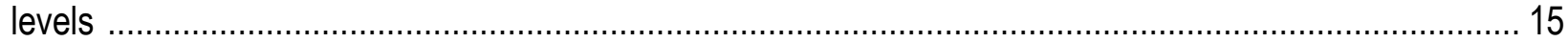

Figure 8. Red Hills: Selected soil physical and chemical data (Soil pH, Electrical conductivity, Water-filled pore space (WFPS), Bulk density) across the study-design levels ...................................................... 16

Figure 9. Red Hills: Selected soil macronutrient data (Total and DTPA-extracable $\mathrm{Ca}$ and $\mathrm{Mg}$ ) across the study-design levels.

Figure 10. Red Hills: Selected soil macronutrient data (Total and DTPA-extractable P) across the study design levels

Figure 11. Red Hills: Selected soil trace metals (Total and DTPA-extractable Ni and $\mathrm{Cr}$ ) across the study design levels.

Figure 12. Red Hills: Selected vegetation data (Aboveground net primary productivity (ANPP), canopy cover,

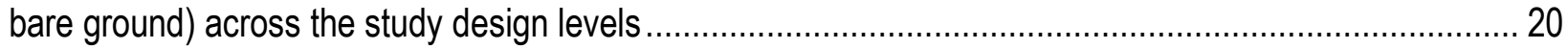

Figure 13. Quartz-alunite sites: Soil microbial data (Enzyme activity) across the study design levels. ................... 21

Figure 14. Quartz-alunite sites: Soil microbial data (Mineralizable $\mathrm{C}$ and N, organic $\mathrm{C}$, total $\mathrm{N}$ ) across the study design levels

Figure 15. Quartz-alunite sites: Soil microbial data (Ecoplate AWCD, microbial biomass (PLFA)) across the study design levels.

Figure 16. Quartz-alunite sites: Selected soil chemical and physical data (Soil pH, EC, water-filled pore space (WFPS), bulk density) across the study design levels.

Figure 17. Quartz-alunite sites: Selected soil macronutrient data (Total and water-soluble P, inorganic N) across the study design levels

Figure 18. Quartz alunite sites: Selected soil macronutrient data (Total and DTPA-extractable $\mathrm{S}$ and $\mathrm{Mg}$ ) across the study design levels 
Figure 19. Quartz-alunite sites: Selected soil metal data (Total and DTPA-extractable Al and Pb) across the study design levels.

Figure 20. Quartz-alunite sites: Selected soil metal data (Total and DTPA-extractable Mn and total Se) across the study design levels.

Figure 21. Quartz-alunite sites: Selected vegetation data (Aboveground net primary productivity (ANPP), bare ground, canopy cover, canopy cover comprised of cheat grass) across the study design levels............... 29

Figure 22. Buckingham: Soil microbial data (Enzyme activity) across the study design levels. 30

Figure 23. Buckingham: Soil microbial data (Mineralizable $\mathrm{C}$ and N, organic $\mathrm{C}$, total $\mathrm{N}$ ) across the study design levels.

Figure 24. Buckingham: Soil microbial data (Ecoplate AWCD, microbial biomass (PLFA)) across the study design levels

Figure 25. Selected soil chemical and physical data (Soil pH, EC, water-filled pore space (WFPS), bulk density) across the study design levels.

Figure 26. Buckingham: Selected soil macronutrient data (Total and water-soluble $P$, inorganic $N$ ) across the study design levels..

Figure 27. Buckingham: Selected soil macronutrient data (Total and DTPA-extractable S and Mg) across the study design levels

Figure 28. Buckingham: Selected soil metal data (Total and DTPA-extractable $\mathrm{Cu}$ and $\mathrm{Zn}$ ) across the study design levels.

Figure 29. Buckingham: Selected soil metal data (Total and DTPA-extractable As and Pb) across the study design levels

Figure 30. Buckingham: Selected vegetation data (Aboveground net primary productivity (ANPP), shrub density, canopy cover, bare ground) across the study design levels.

\section{Tables}

1. Site locations and general characteristics 6

2. Measures of ecosystem function .

3. Measures of metals and relevant chemical and physical parameters

\section{Appendix Tables}

A1. Red Hills Podiform Chromite: Microbial Data

A2. Red Hills Podiform Chromite: Physical and Chemical Data . ................................................................. 12

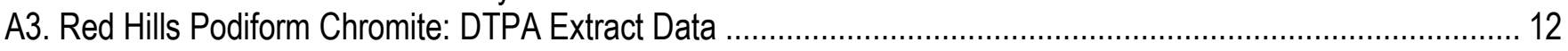

A4. Red Hills Podiform Chromite: Total and Water Extractable Metals Data . ................................................... 12

A5. Red Hills Podiform Chromite: Vegetation Production Data. .................................................................... 12

A6. Red Hills Podiform Chromite: Vegetation Chemical Data. ..................................................................... 12

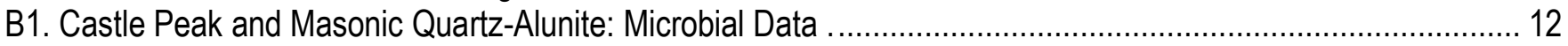

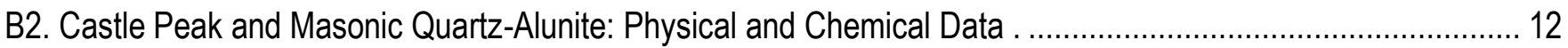

B3. Castle Peak and Masonic Quartz-Alunite: DTPA Extract Data .............................................................. 12

B4. Castle Peak and Masonic Quartz-Alunite: Total and Water Extractable Metals Data .................................... 12

B5. Castle Peak and Masonic Quartz-Alunite: Vegetation Production Data. .................................................... 12

B6. Castle Peak and Mosonic Quartz-Alunite: Vegetation Chemical Data. .......................................................... 12

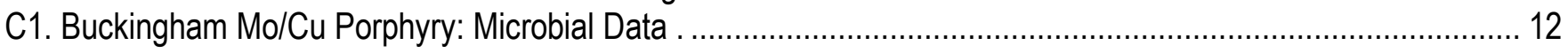

C2. Buckingham Mo/Cu Porphyry: Physical and Chemical Data ............................................................... 12

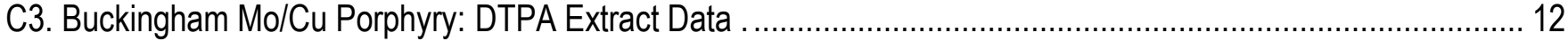

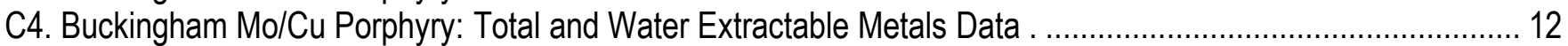

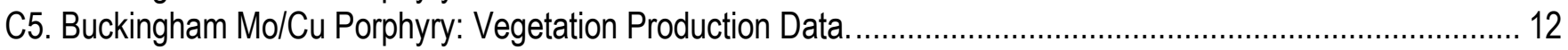

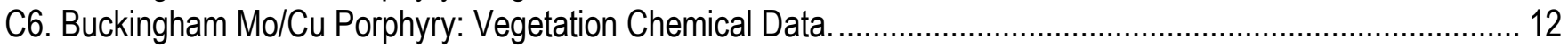




\section{Conversion Factors}

SI to Inch/Pound

\begin{tabular}{|c|c|c|}
\hline Multiply & By & To obtain \\
\hline \multicolumn{3}{|c|}{ Length } \\
\hline millimeter (mm) & 0.03937 & inch (in.) \\
\hline meter $(\mathrm{m})$ & 3.281 & foot $(\mathrm{ft})$ \\
\hline \multicolumn{3}{|c|}{ Area } \\
\hline square meter $\left(\mathrm{m}^{2}\right)$ & 10.76 & square foot $\left(\mathrm{ft}^{2}\right)$ \\
\hline \multicolumn{3}{|c|}{ Volume } \\
\hline cubic centimeter $\left(\mathrm{cm}^{3}\right)$ & 0.06102 & cubic inch $\left(\right.$ in $\left.^{3}\right)$ \\
\hline \multicolumn{3}{|c|}{ Mass } \\
\hline $\operatorname{gram}(\mathrm{g})$ & 0.03527 & ounce, avoirdupois (oz) \\
\hline kilogram (kg) & 2.205 & pound avoirdupois (lb) \\
\hline gram per cubic centimeter $\left(\mathrm{g} / \mathrm{cm}^{3}\right)$ & 62.4220 & pound per cubic foot $\left(\mathrm{lb} / \mathrm{ft}^{3}\right)$ \\
\hline
\end{tabular}

Temperature in degrees Celsius $\left({ }^{\circ} \mathrm{C}\right)$ may be converted to degrees Fahrenheit $\left({ }^{\circ} \mathrm{F}\right)$ as follows:

${ }^{\circ} \mathrm{F}=\left(1.8 \mathrm{x}^{\circ} \mathrm{C}\right)+32$

Vertical coordinate information is referenced to the insert datum name (and abbreviation) here, for instance, "North American Vertical Datum of 1988 (NAVD 88)"

Horizontal coordinate information is referenced to the insert datum name (and abbreviation) here, for instance, "North American Datum of 1983 (NAD 83)"

Altitude, as used in this report, refers to distance above the vertical datum.

Specific conductance is given in decisiemens per meter at 25 degrees Celsius ( $\mathrm{dS} / \mathrm{m}$ at $25^{\circ} \mathrm{C}$ ). 


\title{
Ecosystem Health in Mineralized Terrane-Data from Podiform Chromite (Chinese Camp Mining District, California), Quartz Alunite (Castle Peak and Masonic Mining Districts, Nevada/California), and Mo/Cu Porphyry (Battle Mountain Mining District, Nevada) Deposits
}

\author{
By Steve W. Blecker ${ }^{1}$, Lisa L. Stillings ${ }^{1}$, Michael C. Amacher², James A. Ippolito³, and Nicole M. DeCrappeo 4
}

\section{Introduction}

The myriad definitions of soil/ecosystem quality or health are often driven by ecosystem and management concerns, and they typically focus on the ability of the soil to provide functions relating to biological productivity and/or environmental quality (Doran and Parkin, 1994; Karlen and others, 1997). A variety of attempts have been made to create indices that quantify the complexities of soil quality and provide a means of evaluating the impact of various natural and anthropogenic disturbances. Though not without their limitations (Sojka and Upchurch, 1999), indices can improve our understanding of the controls behind ecosystem processes and allow for the distillation of information to help link scientific and management communities. In terrestrial systems, indices were initially developed and modified for agroecosystems (Doran and Parkin, 1994); however, the number of studies implementing such indices in nonagricultural systems is growing (Bastida and others, 2008). Soil quality indices (SQIs) are typically composed of biological (and sometimes physical and chemical) parameters that attempt to reduce the complexity of a system into a metric of a soil's ability to carry out one or more functions (Papendick and Parr, 1992; Halvorson and others, 1996).

The indicators utilized in SQIs can be as varied as the studies themselves, reflecting the complexity of the soil and ecosystems in which they function. Regardless, effective soil quality indicators should correlate well with soil or ecosystem processes, integrate those properties and processes, and be relevant to management practices (Doran and Parkin, 1996; Dalal, 1998; Nortcliff, 2002). Commonly applied biological indicators include measures associated with soil microbial activity or function (for example, carbon and nitrogen mineralization, respiration, microbial biomass, enzyme activity; Winding and others, 2005). Cost, accessibility, ease of interpretation, and presence of existing data often dictate indicator selection given the number of available measures. We employed a large number of soil biological, chemical, and physical measures, along with measures of vegetation cover, density, and productivity, in order to test the utility and sensitivity of these measures within various mineralized terranes. We were also interested in examining these relations in the context of determining

\footnotetext{
1 U.S. Geological Survey, MS176, University of Nevada, Reno, NV 89557

2 U.S. Forest Service, Logan, UT 84321

3 USDA-Agricultural Research Service, Kimberly, ID 83341

4 U.S. Geological Survey, Corvallis, OR 97331
} 
appropriate reference conditions with which to compare reclamation efforts.

The purpose of this report is to present the data used to develop indices of soil and ecosystem quality associated with mineralized terranes (areas enriched in metal-bearing minerals), specifically podiform chromite, quartz alunite, and $\mathrm{Mo} / \mathrm{Cu}$ porphyry systems. Within each of these mineralized terranes, a nearby unmineralized counterpart was chosen for comparison. The data consist of soil biological, chemical, and physical parameters, along with vegetation measurements for each of the sites described below. Synthesis of these data and index development will be the subject of future publications.

\section{Study Areas}

\section{Red Hills, Bureau of Land Management Area of Critical Concern (near Sonora, California)}

The Chinese Camp mining district in the western Sierra Nevada of Tuolumne County, California, contains Upper Jurassic volcanic and sedimentary rocks that were intruded by ultramafic dunite, which has been partly or entirely serpentinized (Logan, 1949) and contains podiform chromite deposits (deposit model 8a in Cox and Singer, 1992). The podiform chromite formed within the dunite host as the dunite magma solidified and differentiated, and contemporaneous to subsequent alteration by seawater produced the serpentinite. Deposits of chromite, magnesite, and placer gold have been mined in this district sporadically through the 1940s (Logan, 1949). The Red Hills Area of Critical Environmental Concern (as designated by the BLM) is present within this mining district. This area contains a unique ecosystem of endemic vegetation and serpentine soils that are characterized by low $\mathrm{Ca} / \mathrm{Mg}$ ratios and high $\mathrm{Ni}$ and $\mathrm{Cr}$ contents (Kruckeberg, 1984; Proctor, 1999). The vegetation and the red soil coloration made it easy to distinguish between the mineralized (serpentinized) and unmineralized areas (fig. 1). In this study, the unmineralized site consisted of an open woodland/annual grass community derived from andesite bedrock, which is in stark contrast to the adjacent buckbrush chaparral that grows on the serpentinite-derived soils (table 1.) Unlike the other deposit types that were studied, the dunite, due to its origin, does not have an unmineralized phase. The andesite rocks that surround the dunite have a somewhat different origin and chemical composition as the dunite. As a result, the andesite is not a truly unmineralized analog of the dunite, but it is spatially related and is the only unmineralized and unaltered igneous lithology in the district. Mine dumps from defunct chromite and placer gold mines were also sampled. 


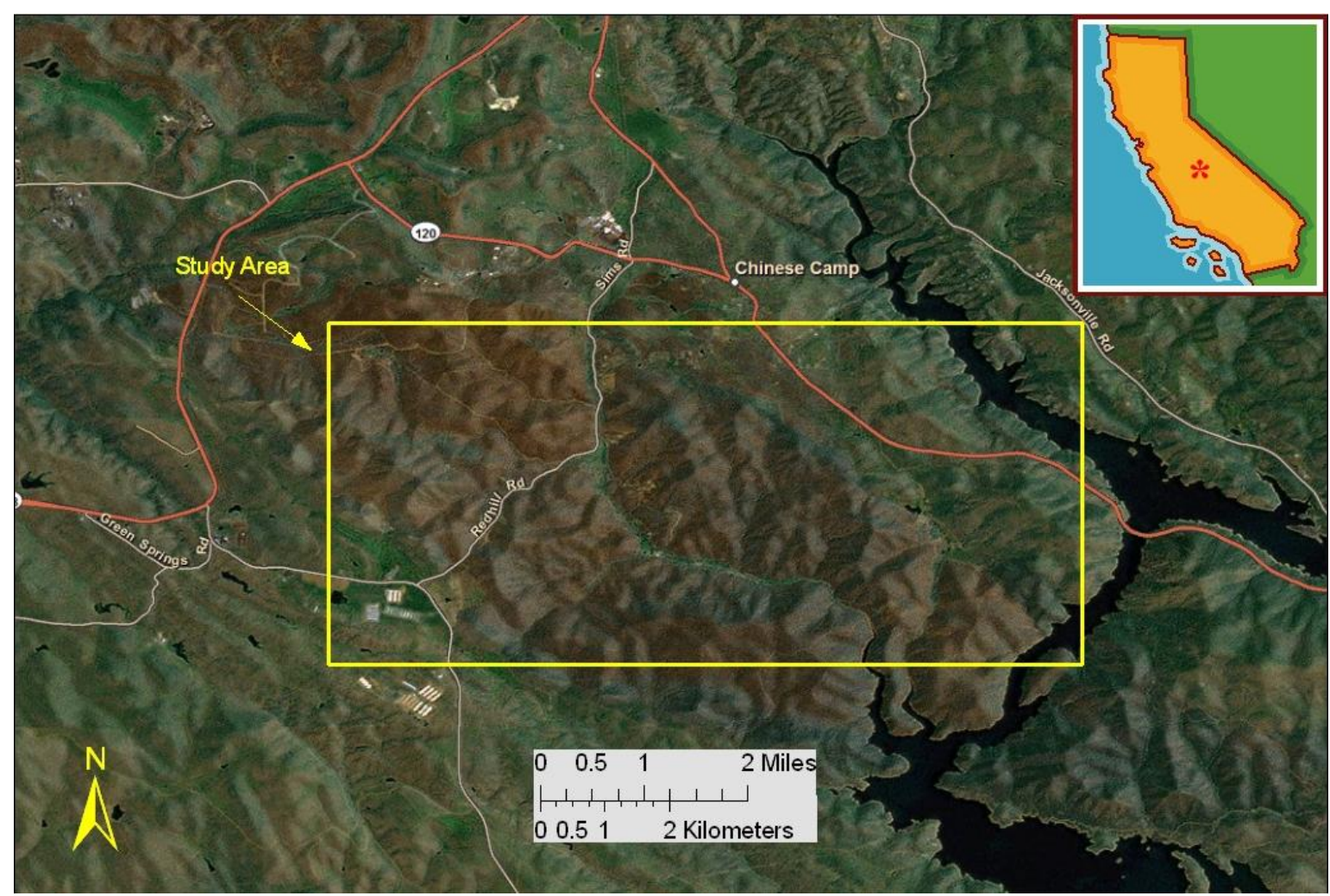

Figure 1. Red Hills (podiform chromite) study area location map, Toulumne County, California. The red soil coloration visible in the imagery is due to limited vegetative cover and high soil-iron content.

\section{Castle Peak (near Reno, Nevada) and Masonic Mining district (near Bridgeport, California)}

The Castle Peak mining district in Washoe and Storey Counties, Nevada (Tingley, 1998) contains large areas of Miocene volcanic rocks that were altered to quartz, alunite, and clays during hydrothermal alteration that occurred at 9 to $16 \mathrm{Ma}$ (deposit model 25e in Cox and Singer, 1992). Precious-metal and mercury deposits formed and occur in or adjacent to areas of alteration (Vikre, 1998). Sites of hydrothermal alteration are characterized by open woodland as compared to unaltered sites characterized by sagebrush shrubland (table 1). Samples were collected in areas with visually obvious quartz-alunite alteration minerals, nonaltered andesites and dacites, and waste-rock and tailings piles at abandoned $\mathrm{Hg}$ and ferricrete mines (fig. 2).

In order to assess the similarity/differences in observations between sites with similar deposit types and climate, we also collected samples at the Masonic mining district in Mineral County, Nevada, and in Mono County, California. This mining district also contains large areas of Miocene andesites and dacites that were subject to periods of hydrothermal quartz-alunite alteration between 7.2 and 8.4 Ma (Silberman, and others, 1972; Chesterman and others, 1986; deposit model 25e in Cox and Singer, 1992). As in the Castle Peak mining district, the hydrothermally altered areas are characterized by open woodland, with sagebrush shrubland communities in adjacent areas of unaltered andesite and dacite. Samples were collected in ecosystems above altered and nonaltered rocks, as well as in nearby wasterock and tailings piles associated with precious-metal mining (fig. 2 ). 


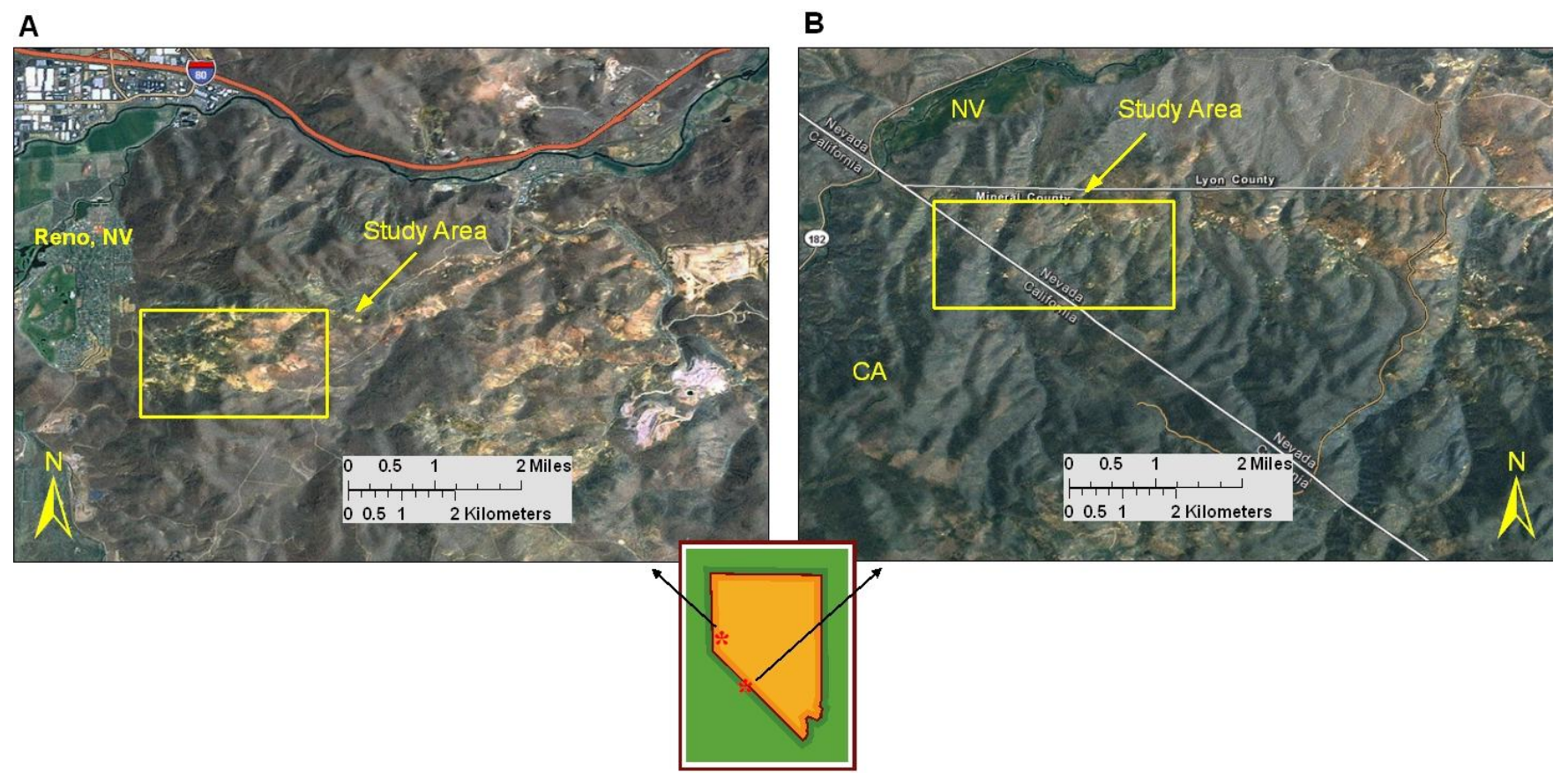

Figure 2. Study area location maps. A, Castle Peak, Washoe and Storey Counties, Nevada; B, Mineral County, Nevada, and Mono County California. The quartz-alunite alteration, which is visible through the limited vegetation, appears as the lighter yellow-colored areas resulting from hydrothermal leaching.

\section{Buckingham (near Battle Mountain, Nevada)}

The Buckingham deposit is a low-fluorine, calc-alkaline stockwork molybdenum-copper system (deposit model 21b in Cox and Singer, 1992) in the Battle Mountain mining district in north-central Nevada. Mineralization occurred during seven major phases of molybdenum-bearing magmatism. The resulting intrusive center consists of two stocks and several outlying intrusive masses, along with regions of $\mathrm{Cu}-, \mathrm{Ag}-$, and W-bearing veins and mineral deposits (Loucks and Johnson, 1992). The surrounding nonmineralized geology is dominated by interbedded arenites, shale and greenstone of the Paleozoic Harmony Formation (Theodore and others, 1992). As the sagebrush communities on both the mineralized and nonmineralized rocks (table 1) do not differ visually, we utilized extensive mapping from Theodore and others (1992) to identify appropriate sampling areas and also sampled from nearby waste-rock and tailings piles (fig. 3). 


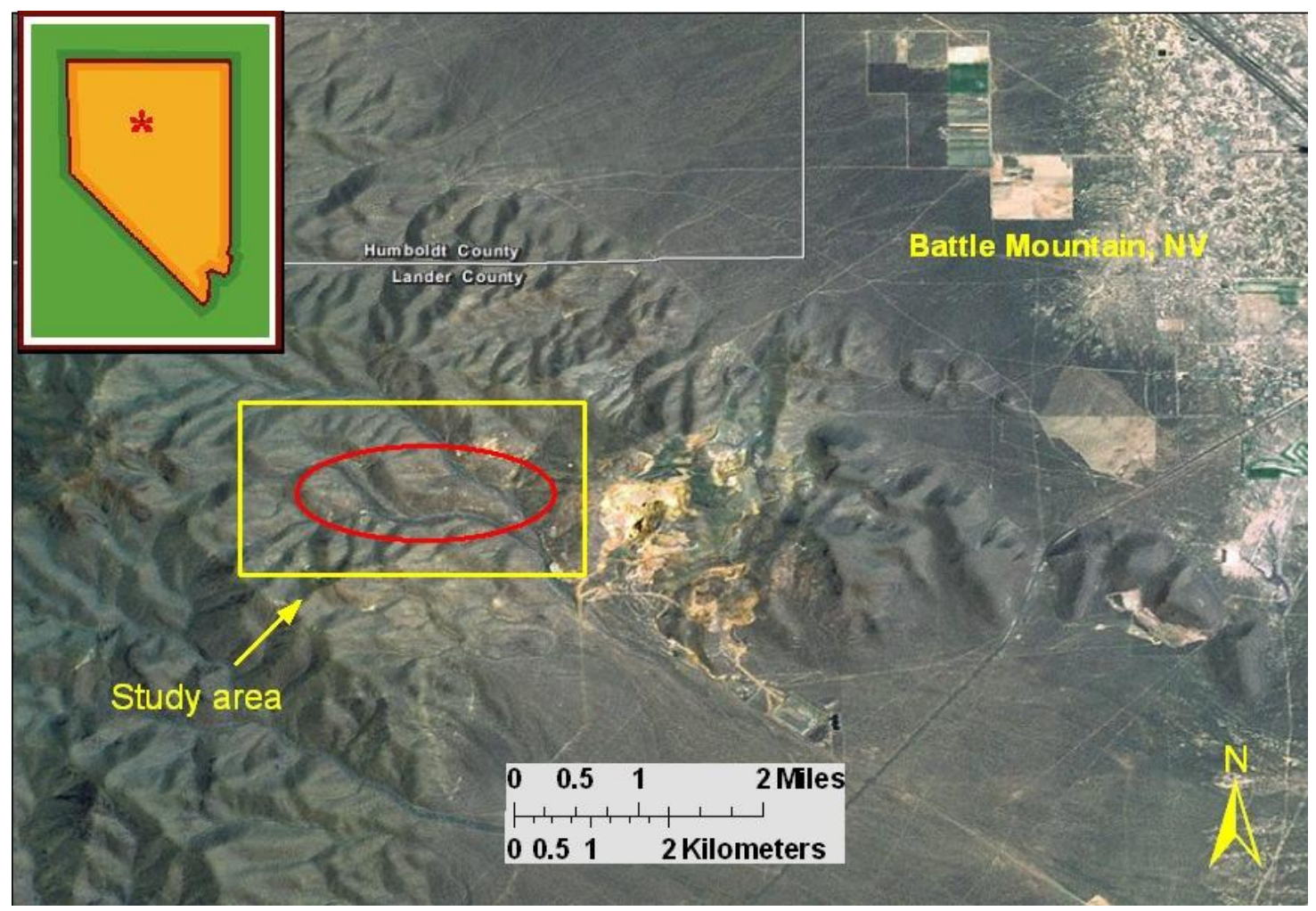

Figure 3. Buckingham (Mo/Cu porphyry) study area location map, north-central, Nevada. The mineralized area is depicted by the red oval within the overall study area. 
Table 1. Site locations and general characteristics for selected mining districts in Nevada and California.

[MAP, Mean annual precipitation; MAT, Mean annual air temperature; $\mathrm{mm}$, millimeter; ${ }^{\circ} \mathrm{C}$, degrees Celsius]

\begin{tabular}{|c|c|c|c|c|c|c|}
\hline \multirow{2}{*}{$\begin{array}{l}\text { Site } \\
\text { (latitude, } \\
\text { longitude) } \\
\text { Elevation }\end{array}$} & Mineralization type & \multirow{2}{*}{$\begin{array}{c}\text { Soil } \\
\text { classification } 1\end{array}$} & \multirow{2}{*}{$\begin{array}{l}\text { Vegetation } \\
\text { community }\end{array}$} & \multirow[b]{2}{*}{ Dominant species } & \multirow{2}{*}{$\begin{array}{l}\text { MAP } \\
\text { in } \mathrm{mm}\end{array}$} & \multirow{2}{*}{$\begin{array}{l}\text { MAT } \\
\text { in }{ }^{\circ} \mathrm{C}\end{array}$} \\
\hline & $\begin{array}{l}\text { Unmineralized } \\
\text { country rock }\end{array}$ & & & & & \\
\hline \multirow{2}{*}{$\begin{array}{l}\text { Red Hills }(\mathrm{RH}) \\
- \text { Sonora, CA } \\
\left(37.85^{\circ} \mathrm{N}\right. \\
\left.120.4^{\circ} \mathrm{W}\right) \\
530 \mathrm{~m}\end{array}$} & $\begin{array}{l}\text { Podiform } \\
\text { chromite }\end{array}$ & $\begin{array}{l}\text { Lithic } \\
\text { Xerochrept }\end{array}$ & $\begin{array}{l}\text { Buckbrush } \\
\text { chaparral }\end{array}$ & $\begin{array}{l}\text { Ceanothus cuneatus, Pinus } \\
\text { sabiniana, Eriogonum } \\
\text { tripodum, Melica californica, } \\
\text { Elymus multisetus }\end{array}$ & \multirow{2}{*}{820} & \multirow{2}{*}{14.9} \\
\hline & Andesite & $\begin{array}{c}\text { Lithic } \\
\text { Haploxeralf }\end{array}$ & $\begin{array}{l}\text { Blue oak } \\
\text { woodland }\end{array}$ & $\begin{array}{l}\text { Quercus douglasii, Pinus } \\
\text { sabiniana, Bromus sp., Avena } \\
\text { fatua, Amsinckia menziesii, } \\
\text { Erodium sp. }\end{array}$ & & \\
\hline \multirow{2}{*}{$\begin{array}{c}\text { Castle Peak } \\
(\mathrm{CP})-\text { Reno, } \\
\mathrm{NV} \\
\left(39.48^{\circ} \mathrm{N}\right. \\
\left.119.7^{\circ} \mathrm{W}\right) \\
1,350 \mathrm{~m}\end{array}$} & $\begin{array}{c}\text { Epithermal } \\
\text { quartz-alunite Au }\end{array}$ & $\begin{array}{c}\text { Xeric } \\
\text { Torriorthent }\end{array}$ & $\begin{array}{c}\text { Pine } \\
\text { woodland }\end{array}$ & $\begin{array}{l}\text { Pinus jeffreyii, Pinus } \\
\text { monophylla, Pinus } \\
\text { ponderosa, Eriogonum } \\
\text { robustum }\end{array}$ & \multirow[b]{2}{*}{185} & \multirow[b]{2}{*}{10.4} \\
\hline & Andesite, Dacite & $\begin{array}{l}\text { Xerollic } \\
\text { Haplargid }\end{array}$ & $\begin{array}{l}\text { Sagebrush/ } \\
\text { pinion- } \\
\text { juniper }\end{array}$ & $\begin{array}{l}\text { Artemisia tridentata, } \\
\text { Achnatherum thurberianum, } \\
\text { Poa secunda, Elymus } \\
\text { elymoides, Pinus } \\
\text { monophylla, Juniperous } \\
\text { osteosperma }\end{array}$ & & \\
\hline \multirow{2}{*}{$\begin{array}{l}\text { Masonic (MA) - } \\
\text { Bridgeport, CA } \\
\left(38.40^{\circ} \mathrm{N}\right. \\
\left.119.1^{\circ} \mathrm{W}\right) \\
2,125 \mathrm{~m}\end{array}$} & $\begin{array}{c}\text { Epithermal } \\
\text { quartz-alunite Au }\end{array}$ & $\begin{array}{c}\text { Xeric } \\
\text { Torriorthent }\end{array}$ & $\begin{array}{c}\text { Pine } \\
\text { woodland }\end{array}$ & $\begin{array}{l}\text { Pinus jeffreyii, Pinus } \\
\text { monophylla, Pinus } \\
\text { ponderosa, Eriogonum } \\
\text { robustum }\end{array}$ & \multirow{2}{*}{210} & \multirow{2}{*}{5.0} \\
\hline & Andesite, Dacite & $\begin{array}{c}\text { Lithic Xerollic } \\
\text { Haplargid }\end{array}$ & $\begin{array}{l}\text { Sagebrush/ } \\
\text { pinion- } \\
\text { juniper }\end{array}$ & $\begin{array}{l}\text { Artemisia arbuscula, } \\
\text { Achnatherum thurberianum, } \\
\text { Pinus monophylla, } \\
\text { Juniperous osteosperma }\end{array}$ & & \\
\hline \multirow{2}{*}{$\begin{array}{l}\text { Buckingham } \\
\text { (BK) - Battle } \\
\text { Mt. NV } \\
\left(40.57^{\circ} \mathrm{N}\right. \\
\left.117.1^{\circ} \mathrm{W}\right) \\
1,380 \mathrm{~m}\end{array}$} & $\begin{array}{c}\text { Porphyry Cu-Mo, } \\
\text { low F }\end{array}$ & $\begin{array}{l}\text { Xerollic } \\
\text { Haplargid }\end{array}$ & $\begin{array}{l}\text { Sagebrush } \\
\text { shrubland }\end{array}$ & $\begin{array}{l}\text { Artemisia nova, } \\
\text { Artemisia tridentata, } \\
\text { Pseudoroegneria spicata, } \\
\text { Achnatherum thurberianum, } \\
\text { Achnatherum hymenoides }\end{array}$ & \multirow{2}{*}{210} & \multirow{2}{*}{9.5} \\
\hline & $\begin{array}{c}\text { Arenites, Shale, } \\
\text { Greenstone }\end{array}$ & $\begin{array}{l}\text { Xerollic } \\
\text { Haplargid }\end{array}$ & $\begin{array}{l}\text { Sagebrush } \\
\text { shrubland }\end{array}$ & $\begin{array}{l}\text { Artemisia nova, } \\
\text { Artemisia tridentata, } \\
\text { Pseudoroegneria spicata, } \\
\text { Achnatherum thurberianum, } \\
\text { Achnatherum hymenoides }\end{array}$ & & \\
\hline
\end{tabular}

${ }^{1}$ Soil Survey Staff (2006) 


\section{Sampling and Analyses}

\section{Study Design/Field Sampling}

The study design is represented schematically in figure 4 and described below. Within each of the four study areas (three deposit types plus one duplicate), three random locations were selected within each of the three study-design levels [undisturbed/mineralized, undisturbed/nonmineralized, disturbed/mineralized (waste-rock and tailings piles)]. Each location within a given level was situated on a similar aspect $\left(150^{\circ}\right.$ to $\left.210^{\circ}\right)$, elevation, and slope within the same subwatershed. At each of the locations, three 30-m transects (spaced 120-m apart) were established. One soil sample (collected at 0$15 \mathrm{~cm}$ depth, after gently removing any $\mathrm{O}$ horizon or litter material) was taken at a random location along each transect for a total of 9 samples per 'treatment' at each of the four sites. In order to minimize small-scale spatial variability and effect a more equivalent comparison among the treatments, samples were collected outside of the canopy of any trees or shrubs. For the Buckingham site only, an additional study-design level was added to examine soil variability under and between the shrub canopy within the undisturbed/mineralized and undisturbed/nonmineralized design levels. The "under and between canopy" samples were collected at each of the three transects using the same sampling procedure.

The same 30-m transects were used for vegetation measurements. A line-point intercept with 0.6-m intervals was used to determine percentage of canopy cover and percentage of bare ground ( $n=150$ per level). A 4-m belt transect was used to determine densities of trees (categorized by species) and shrubs [categorized as sagebrush (Artemisia sp.), rabbitbrush (Crysothamnus sp.), or other]. Above-ground net primary productivity (ANPP) was estimated by harvesting all living plant material within 0.5 by $0.5 \mathrm{~m}$ quadrats at three random locations along each transect $(\mathrm{n}=27$ per level). Sites were sampled one time in the spring (2008) near peak spring soil moisture/microbial activity (Red Hills, early April; Castle Peak and Buckingham, early and late May respectively; Masonic, mid-June). 

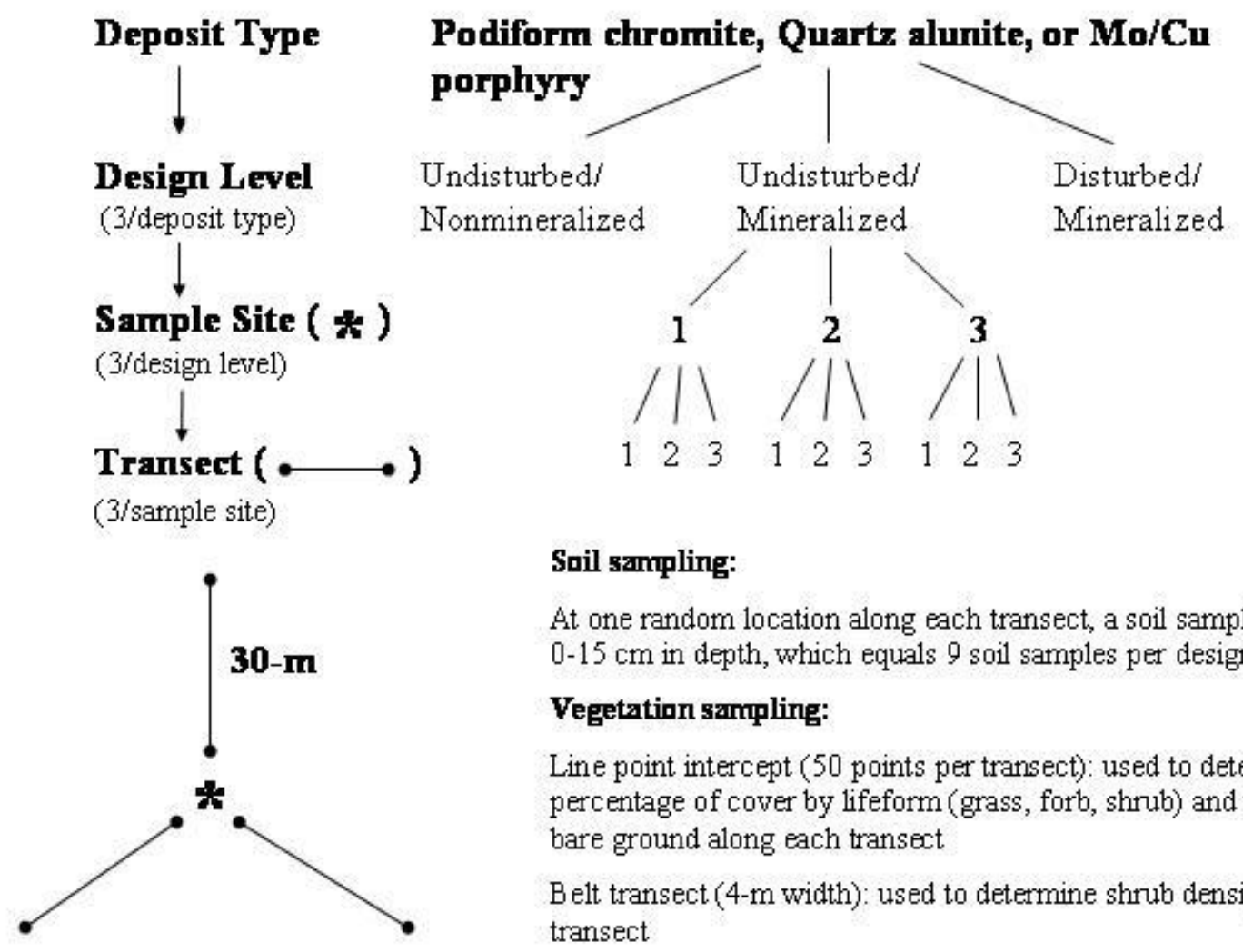

\section{Sail sampling:}

At one random location along each transect, a soil sample was taken from $0-15 \mathrm{~cm}$ in depth, which equals 9 soil samples per design level.

\section{Vegetation sampling:}

Line point intercept ( 50 points per transect): used to determine the percentage of cover by lifeform (grass, forb, shrub) and the percentage of bare ground along each transect

Belt transect (4-m width): used to determine shrub density along each transect

Quadrats ( 0.5 by $0.5 \mathrm{~m}, 3$ per transect): used to determine Aboveground Net Primary Productivity

Figure 4. Study-design schematic.

\section{Analytical Methods}

Analytical methods are outlined in tables 2 and 3. Additional detail for the soil microbial methods follows. All enzyme assays in this study are measurements of potential activity using shortterm incubations at controlled temperature and $\mathrm{pH}$, and were analyzed spectrophotometrically against a standard curve of known substrate concentrations. C and $\mathrm{N}$ soil-mineralization potential was performed in closed vessels for $10-\mathrm{d}$ at $25^{\circ} \mathrm{C}$ as outlined in table 2 . Community-level physiological profiling (CLPP) provides an estimate of bacterial community functional diversity using Biolog EcoPlates (Biolog Inc., Hayward, California, USA). Data presented are all from day 4 (96-hr) spectrophotometric readings to allow for maximum well response variance without exceeding the linear absorbance range (Garland, 1996). All Ecoplate data were corrected using the blank cell, and then separately divided by the respective plate's Average well color development (AWCD), in order to normalize against potential differences in bacterial inoculum density. To provide an estimate of microbial biomass and community structure, we used phospholipid fatty-acid (PLFA) analysis. Certain lipid "signatures" within the cell membranes of living microbes can be used to identify a portion of the microbial community: gram + and gram - bacteria, fungi, actinomycetes, and protozoa (Sinsabaugh et al. 1999). Extracted lipids from 
freeze-dried soil were resuspended in a hexane and MTBE solution and analyzed on a gas chromatograph with a flame ionization detector (GC/FID). Microbial biomass $\mathrm{C}$ was determined as the sum of the phospholipid fatty acids extracted from all microbes.

\section{Table 2. Measures of ecosystem function.}

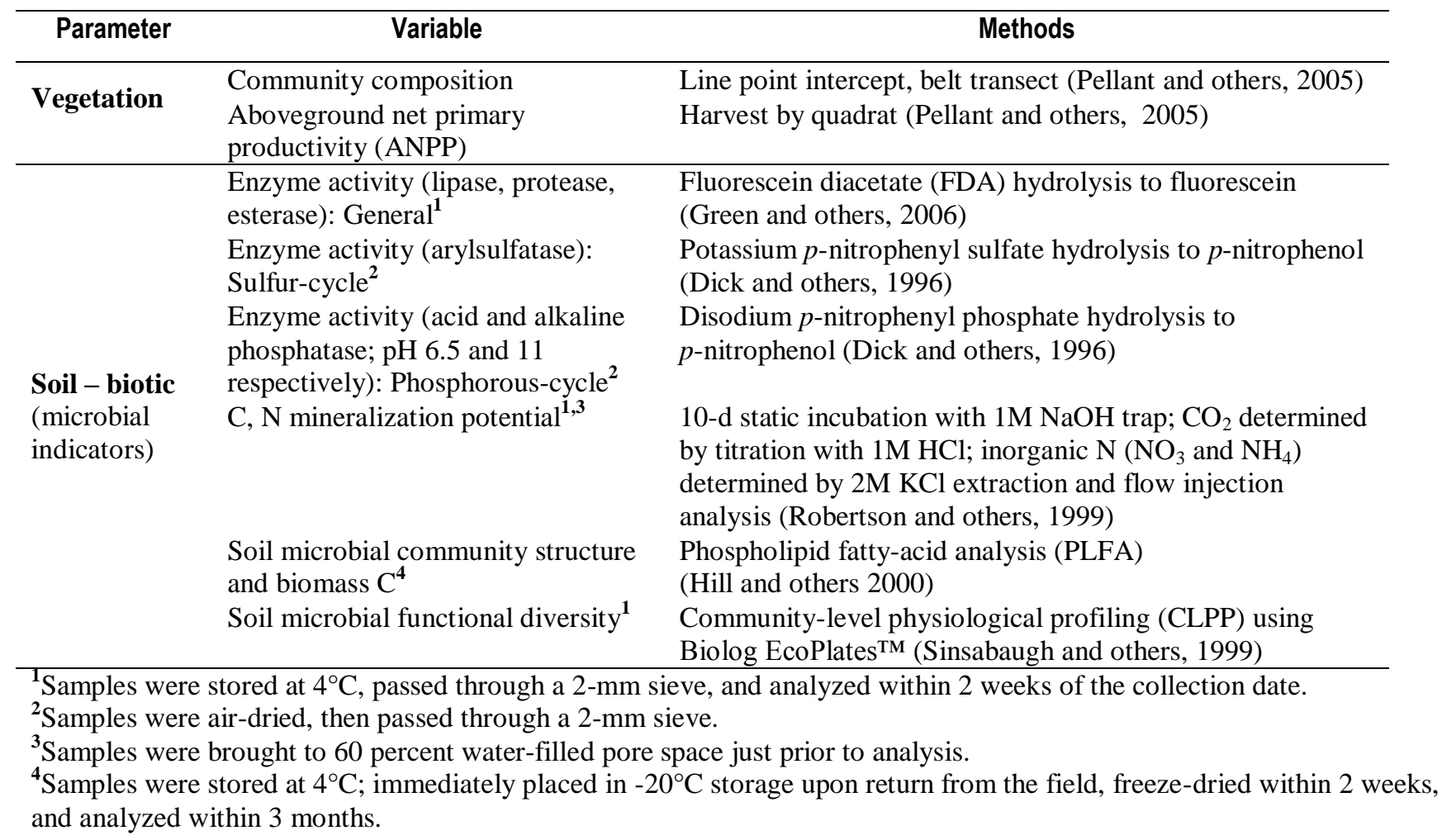


Table 3. Metals concentrations and relevant chemical and physical parameters.

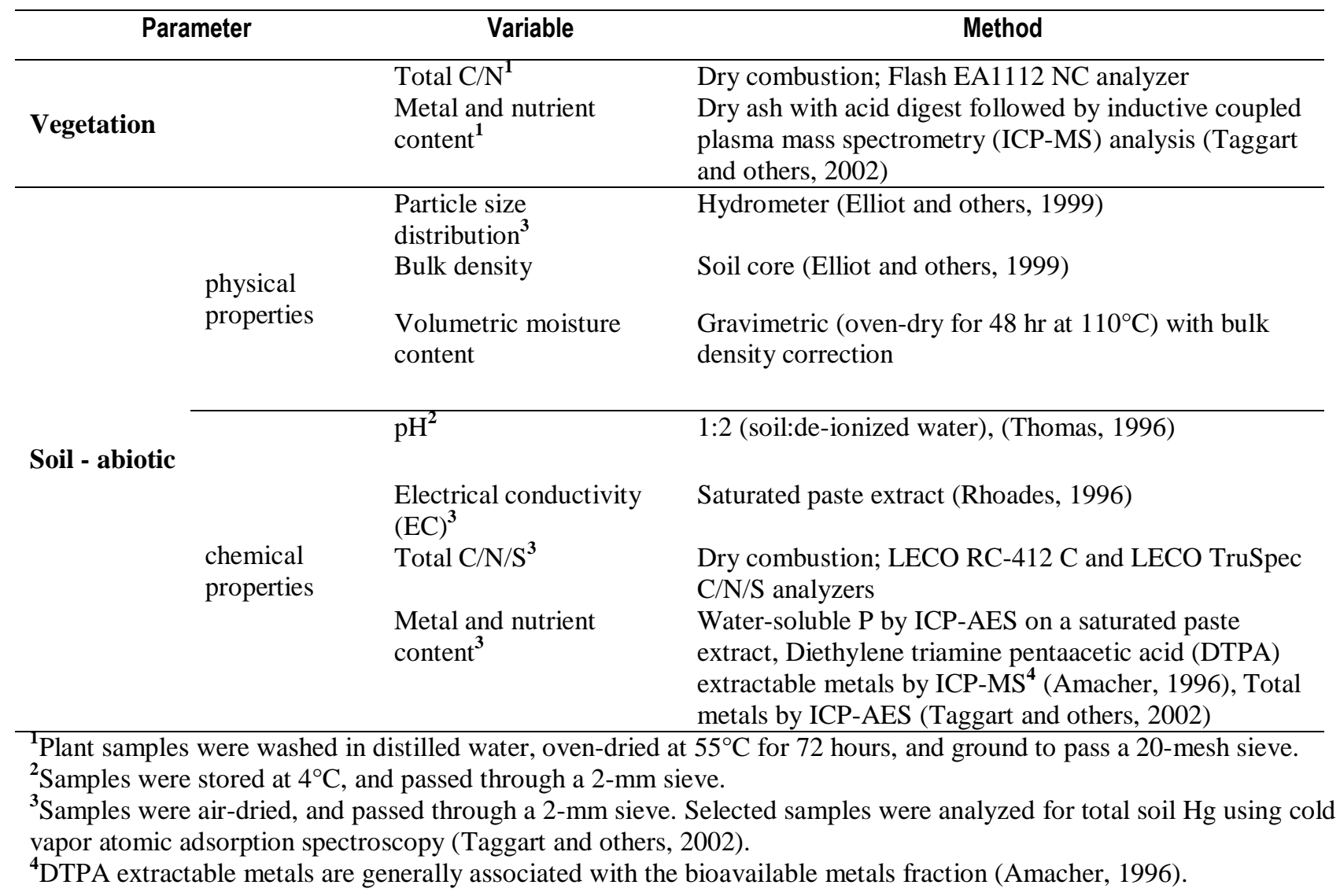

\section{Results}

The entire data set is presented in tabular form by study site as Excel worksheets. The quartz-alunite sites (Castle Peak and Masonic) have been combined into one table. Where applicable, censored values (data below the detection limit) were replaced with a value of $1 / 2$ the lower limit of detection (see tabular data for more detail). Selected data from each study site are presented as box plots (see figs. 530). The line within a given box represents the median. The lower and upper boundaries of the box represent the 25th and 75th percentiles, respectively. Error bars above and below each box represent the 90th and 10th percentiles, respectively. All values listed as a percentage are by weight.

\section{Acknowledgments}

The authors wish to acknowledge all those who assisted with this project. The Bureau of Land Management (Folsom, California) was instrumental in providing access for field sampling associated with Red Hills study area. Washoe County Parks and Recreation Department provided access for sample sites within the Castle Peak area. Alan Wallace, Peter Vikre, Lorre Moyer, and Patty Schumacher of the USGS Western Mineral Team - Reno, Nevada were helpful in providing advice and assistance in the field and office. Paul Lamothe, Larry Gough, and Bronwen Wang of the U.S. Geological Survey provided advice regarding study design and laboratory techniques. 


\section{References Cited}

Amacher, M.C., 1996, Nickel, cadmium, and lead, in Bartels, J.M., ed., Chemical Methods, part 3 of Methods of soil analysis: Soil Science Society of America, Madison, Wisconsin, p. 739-768.

Bastida, F., Zsolnay, A., Hernandez, T., Garcia, C., 2008, Past, present, and future of soil quality indices - a biological perspective: Geoderma, v. 147, p. 59-171.

Chesterman, C., Chapman, R. Gray, C., 1986, Geology and ore deposits of the Bodie mining district, Mono County, California: California Bureau of Mines and Geology Publication 206, 36 p.

Cox, D.P., Singer, D.A., eds., 1992, Mineral deposit models: U.S. Geological Survey Bulletin 1693, 379 p. [http://pubs.usgs.gov/bul/b1693/].

Dalal, R.C., 1998, Soil microbial biomass-what do the numbers really mean?: Australian Journal of Experimental Agriculture, v. 38, p. 649-665.

Dick, R.P., Breakwell, D.P., Turco, R.F., 1996, Soil enzyme activities and biodiversity measurements as integrative microbiological indicators, in Doran, J.W., and Jones, A.J., eds., Methods for assessing soil quality: Soil Science Society of America Special Publication 49, p. 247-271.

Doran, J.W., Parkin, T.B., 1994, Defining and assessing soil quality, in Doran, J.W., and others, eds., Defining soil quality for a sustainable environment: Soil Science Society of America Special Publication 34, p. 3-21.

Doran, J.W., and Parkin, T.B., 1996, Quantitative indicators of soil quality-A minimum data set, in Doran, J.W., and Jones, A.J., eds., Methods for assessing soil quality: Soil Science Society of America Special Publication 49, p. 25-37.

Elliott, E.T., Heil, J.W., Kelly, E.F., Monger, H.C., 1999, Soil structural and other physical properties, in Robertson, G.P., and others, eds., Standard soil methods for long-term ecological research: New York, Oxford University Press, p. 74-85.

Garland, J.L., 1996, Analytical approaches to the characterization of samples of microbial communities using patterns of potential C source utilization: Soil Biology and Biochemistry, v. 28, p. 213-221.

Green, V.S., Stott, D.E., Diack, M., 2006, Assay for fluorescein diacetate hydrolytic activity: Optimization for soil samples: Soil Biology and Biochemistry, v. 38, p. 693-701.

Halvorson, J.J., Smith, J.L., Papendick, R.I., 1996, Integration of multiple soil parameters to evaluate soil quality: a field experiment example: Biology and Fertility of Soils, v. 21, p. 207-214.

Hill, G.T., Mitkowski, N.A., Aldrich-Wolfe, L., Emele, L.R., Jurkonie, D.D., Ficke, A., MaldonadoRamirez, S., Lynch, S.T., Nelson, E.B., 2000, Methods for assessing the composition and diversity of soil microbial communities: Applied Soil Ecology, v. 15, p. 25-36.

Karlen, D.L., Mausbach, M.J., Doran, J.W., Cline, R.G., Harris, R.F., Schuman, G.E., 1997, Soil quality, A concept, definition, and framework for evaluation: Soil Science Society of America Journal, v. 61, p. 4-10.

Kruckeberg, A.R., 1984, California Serpentines, Flora, Vegetation, Geology, Soils and Management Problems: Berkeley, California, University of California Press, 180 p.

Logan, C.A., 1949, Mines and mineral resources of Tuolumne County, California: California Journal of Mines and Geology, v. 45, p.47-83.

Loucks, T.A. and Johnson, C.A., 1992, Economic Geology. In Theodore, T.G., Blake, D.W., Loucks, T.A., and Johnson, C.A., eds., Geology of the Buckingham stockwork molybdenum deposit and surrounding area, Lander County, Nevada: U.S. Geological Survey Professional Paper 798-D, p. D101-D138 [http://pubs.er.usgs.gov/usgspubs/pp/pp798D]. 
Nortcliff, S., 2002, Standardization of soil quality attributes: Agriculture Ecosystems and Environment, v. 88, p. 161-168.

Papendick, R.I., Parr, J.F., 1992, Soil quality-the key to a sustainable agriculture: American Journal of Alternative Agriculture, v. 7, p. 2-3.

Pellant, M., Pyke, D.A., Shaver, P., Herrick, J.E., 2005, Interpreting indicators of rangeland health, Version 4, TR-1734-6: Denver, Colorado, Bureau of Land Management, 136 p.

Proctor, J., 1999, Toxins, nutrient shortages and droughts, The serpentine challenge: Tree Physiology, v. 14, p. 334-335.

Rhoades, J.D., 1996, Salinity: Electrical conductivity and total dissolved solids, in Bartels, J.M., ed., Chemical methods, part 3 of Methods of soil analysis: Soil Science Society of America, Madison, Wisconsin, p. 417-435.

Robertson, G.P., Wedin, D., Groffman, P.F., Blair, J.M., Holland, E.A., Nadelhoffer, K.J., Harris, D., 1999, Soil carbon and nitrogen availability; Nitrogen mineralization, nitrification, and soil respiration potential, in Robertson, G.P., and others, eds., Standard soil methods for long-term ecological research: New York, Oxford University Press, p. 258-271.

Silberman, M.L., Chesterman, C.W., Kleinhampl, F.J., Gray C.H. Jr., 1972, K-Ar ages of volcanic rocks and gold bearing quartz-adularia veins in the Bodie Mining District, Mono County, California: Economic Geology, v. 67, p. 597-603.

Sinsabaugh, R.L., Klug, M.J., Collins, H.P., Yeager, P.E., Petersen, S.O., 1999, Characterizing soil microbial communities, in Robertson, G.P., and others, eds., Standard soil methods for longterm ecological research: New York, Oxford University Press, p. 318-348.

Soil Survey Staff, 2006, Keys to soil taxonomy, 10th ed.: USDA-Natural Resources Conservation Service, Washington, DC, $333 \mathrm{p}$.

Sojka, R.E., Upchurch, R.R., 1999, Reservation regarding the soil quality concept: Soil Science Society of America Journal, v. 63, p.1039-1054.

Taggart, J.E., Jr., ed., 2002, Analytical method for chemical analysis of geologic and other materials, U.S. Geological Survey: U.S. Geological Survey Open-file Report 02-0223 [http://pubs.usgs.gov/of/2002/ofr-02-0223/].

Theodore, T.G., Blake, D.W., Loucks, T.A., Johnson, C.A., 1992, Geology of the Buckingham stockwork molybdenum deposit and surrounding area, Lander County, Nevada: U.S. Geological Survey Professional Paper 798-D, 307 p. [http://pubs.er.usgs.gov/usgspubs/pp/pp798D].

Thomas, G.W., 1996, Soil pH and soil acidity, in Bartels, J.M., ed., Chemical methods, part 3 of Methods of soil analysis: Soil Science Society of America, Madison, Wisconsin, p. 475-490.

Tingley, J.V., 1998, Mining districts of Nevada: NV Bureau of Mines and Geology Report 47, 329 p.

Vikre, P.G., 1998, Quartz-alunite alteration in the western part of the Virginia Range, Washoe and Storey Counties, Nevada: Economic Geology, v. 93, p. 338-346.

Winding, A., Hund-Rinke, K., Rutgers, M., 2005, The use of microorganisms in ecological soil classification and assessment concepts: Ecotoxicology and Environmental Safety, v. 62, p. 230-248.

\section{Appendix}

All of the appendix tables can be accessed using the following link: http://pubs.usgs.gov/of/2010/1040/tables/ 

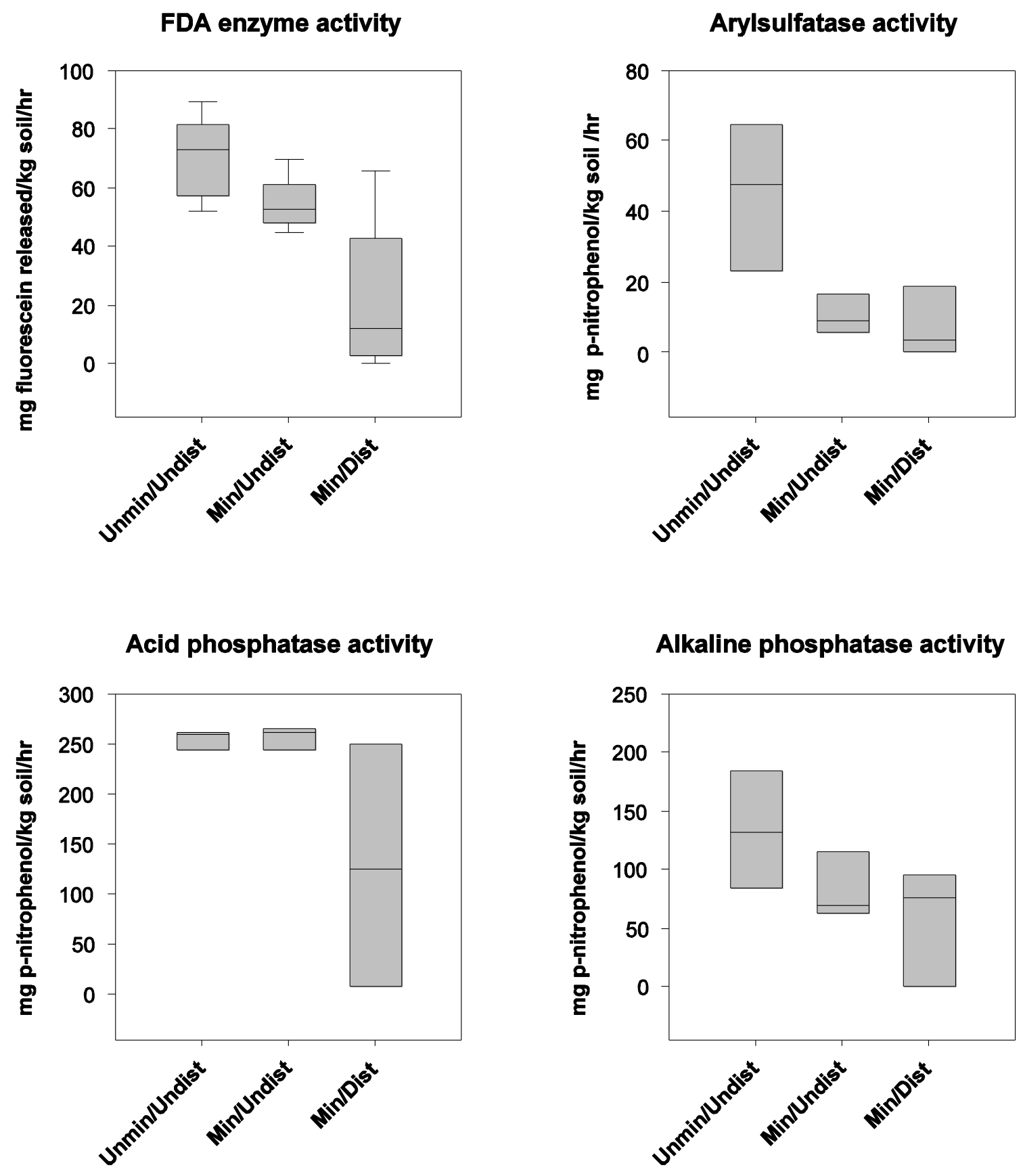

Figure 5. Red Hills study area, Tuolumne County, Calif.: Soil microbial data (Enzyme activity) across the studydesign levels. Unmin/Undist, unmineralized/undisturbed (serpentinite soils); Min/Undist, mineralized/undisturbed (andesite soils); Min/Dist = mineralized/disturbed (waste-rock and tailings piles); FDA, Fluorescein diacetate. 
Potentially mineralizable C

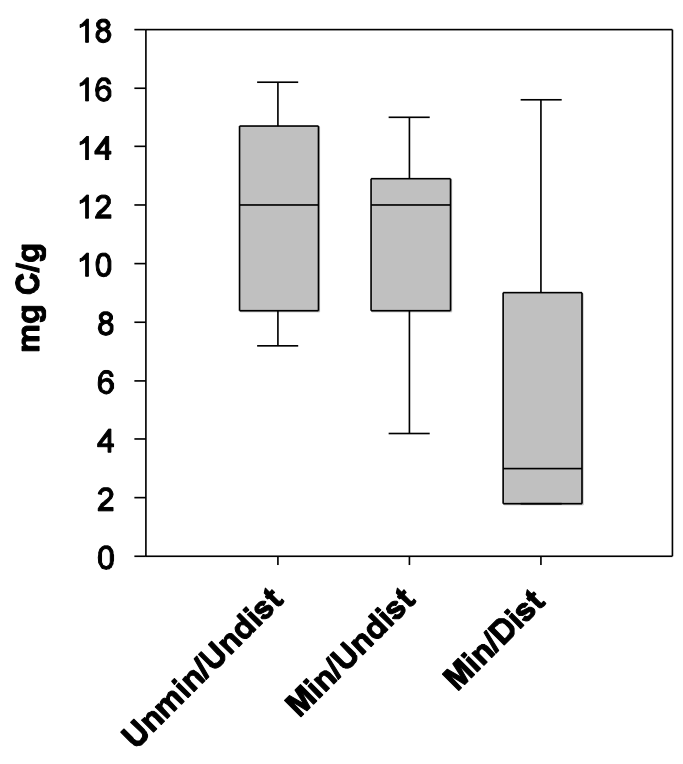

Soil Organic C (\%)

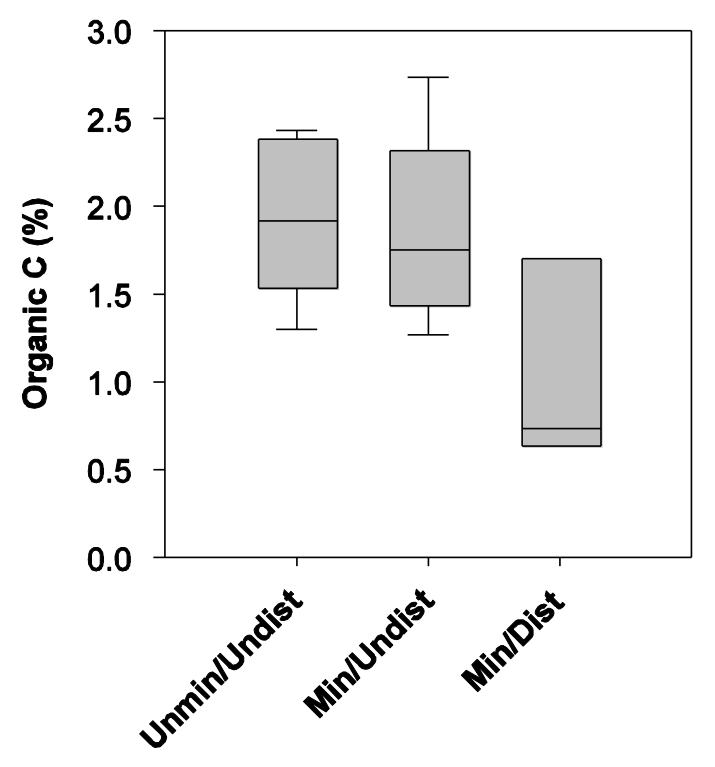

Potentially mineralizable $\mathbf{N}$

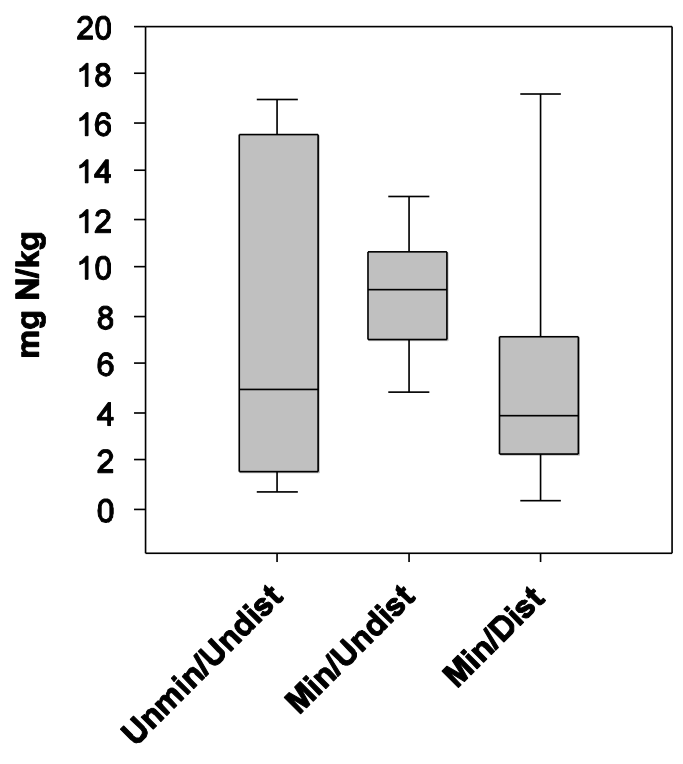

Total Soil N (\%)

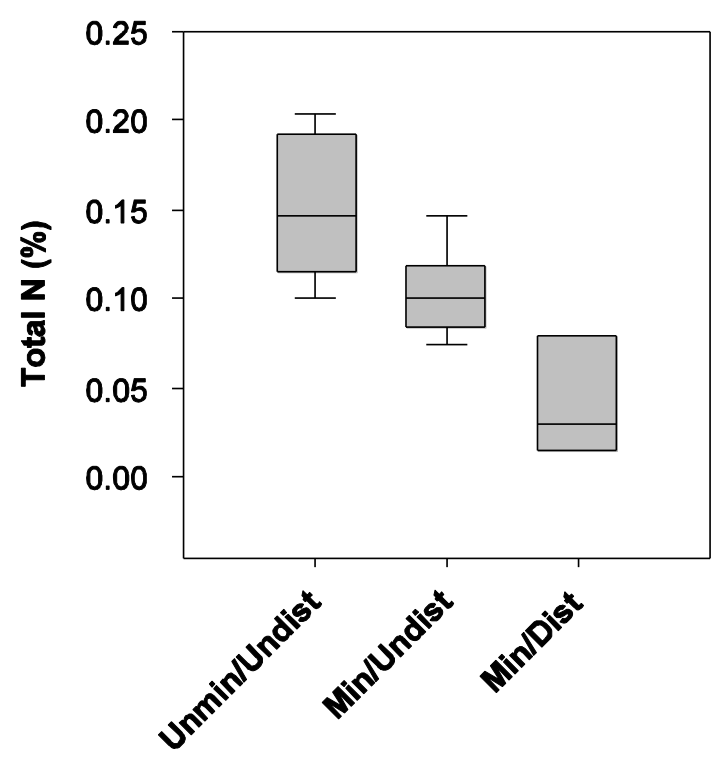

Figure 6. Red Hills study area, Tuolumne County, Calif.: Soil microbial data (Mineralizable $\mathrm{C}$ and N, Organic $\mathrm{C}$, and Total N) across the study-design levels. Unmin/Undist, unmineralized/undisturbed (serpentinite soils); Min/Undist, mineralized/undisturbed (andesite soils); Min/Dist = mineralized/disturbed (waste-rock and tailings piles). 
Ecoplate: AWCD (Day 4)

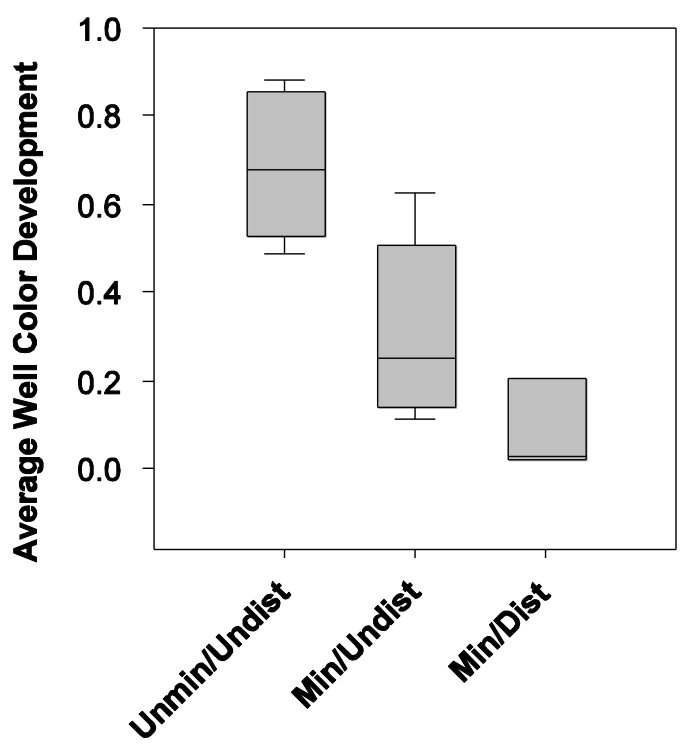

Microbial biomass (PLFA)

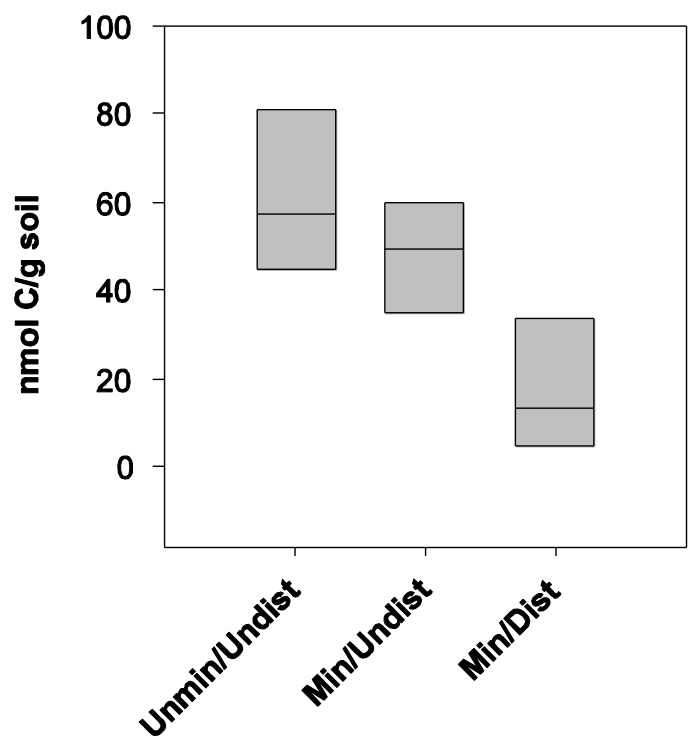

Figure 7. Red Hills study area, Tuolumne County, Calif.: Soil microbial data (Ecoplate AWCD, Microbial biomass (PLFA)) across the study-design levels. Unmin/Undist, unmineralized/undisturbed (serpentinite soils); Min/Undist, mineralized/undisturbed (andesite soils); Min/Dist, mineralized/disturbed (waste-rock and tailings piles), AWCD, Average well color development; PLFA, Phospholipid fatty acids. 
Soil pH

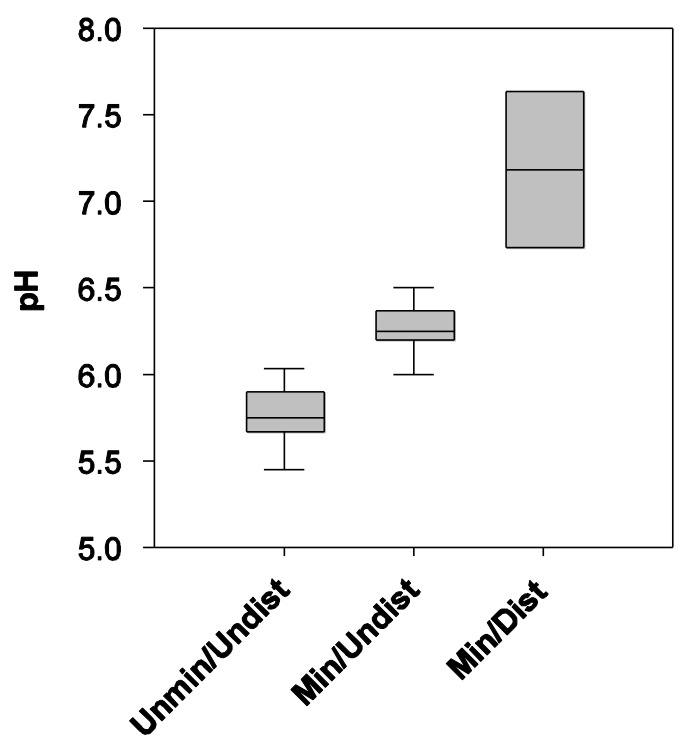

Water-Filled Pore Space (\%)

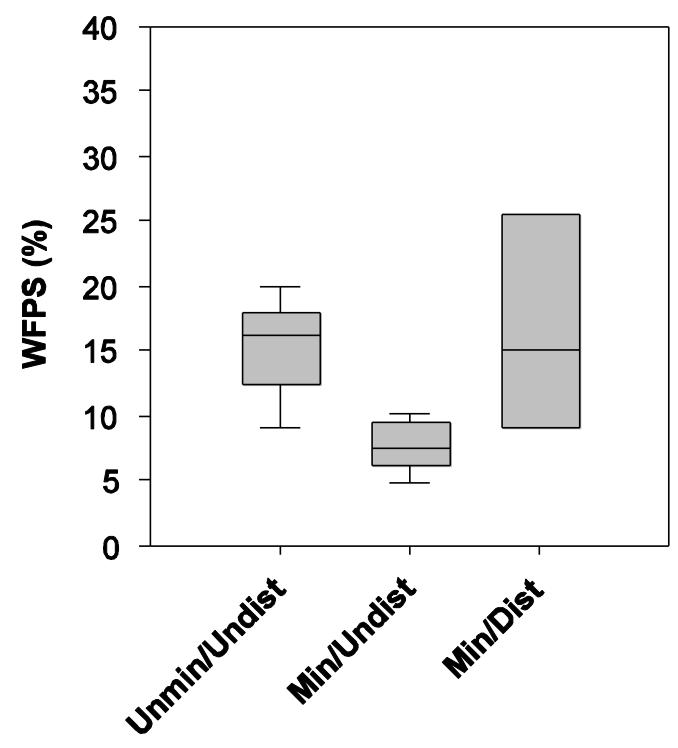

Electrical conductivity (EC)

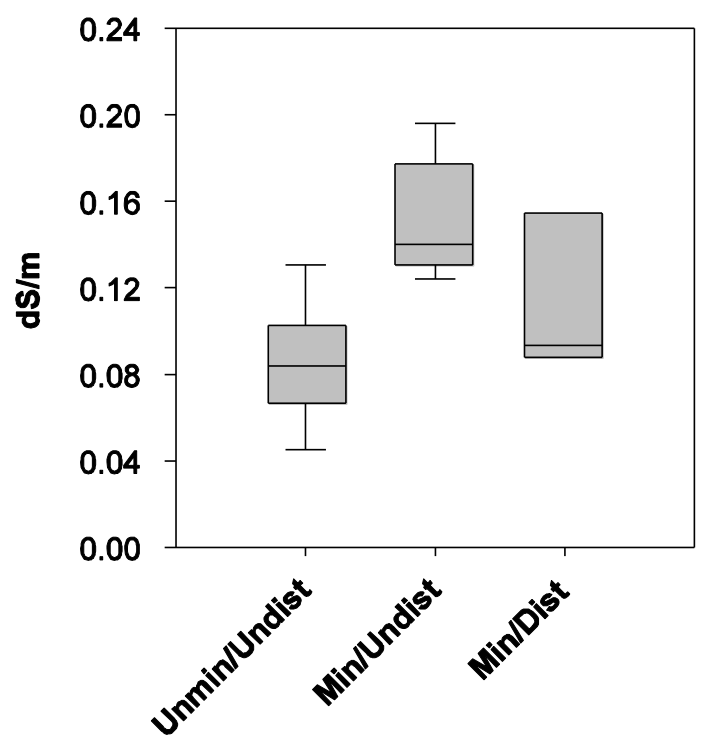

Bulk Density

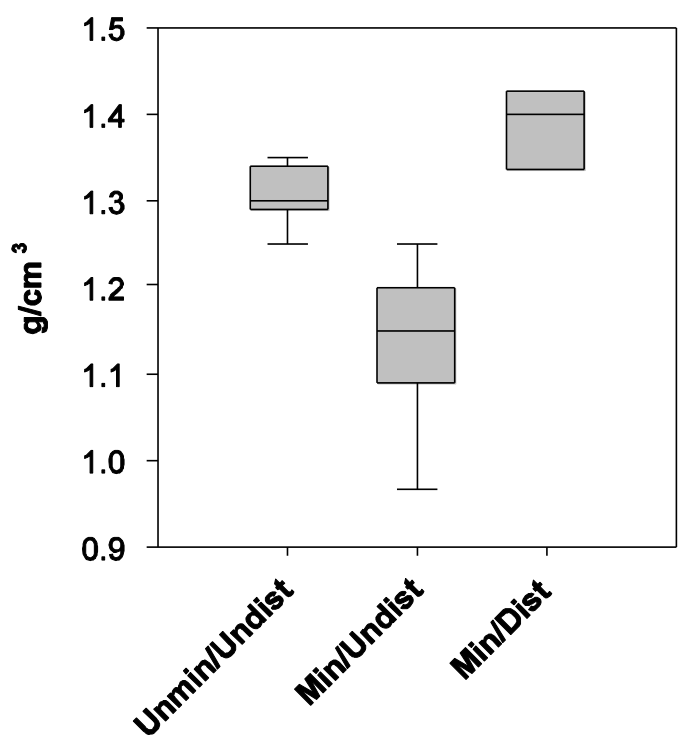

Figure 8. Red Hills study area, Tuolumne County, Calif.: Selected soil physical and chemical data (Soil pH, Electrical conductivity, Water-filled pore space (WFPS), and Bulk density) across the study-design levels. Unmin/Undist, unmineralized/undisturbed (serpentinite soils); Min/Undist, mineralized/undisturbed (andesite soils); Min/Dist, mineralized/disturbed (waste-rock and tailings piles); $d S$ = decisiemens. 
Total soil-Ca

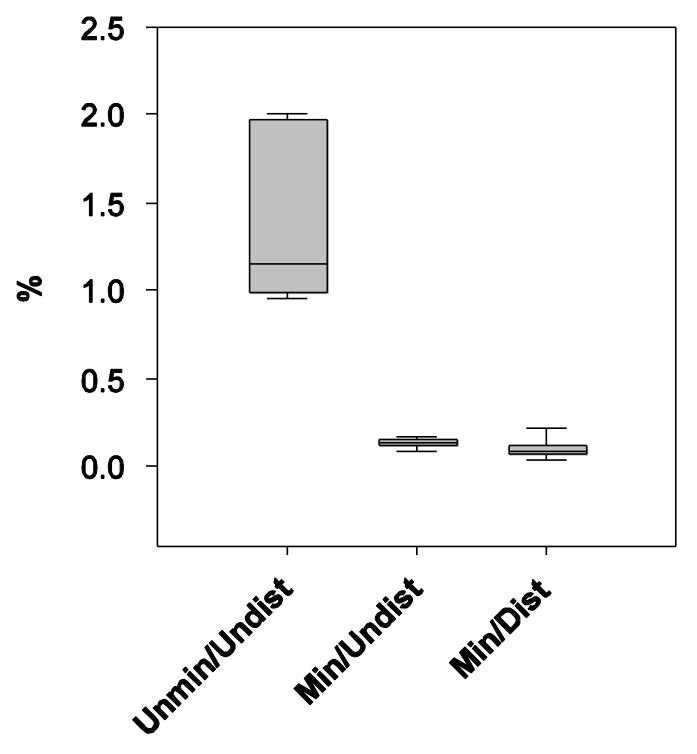

Total soil-Mg

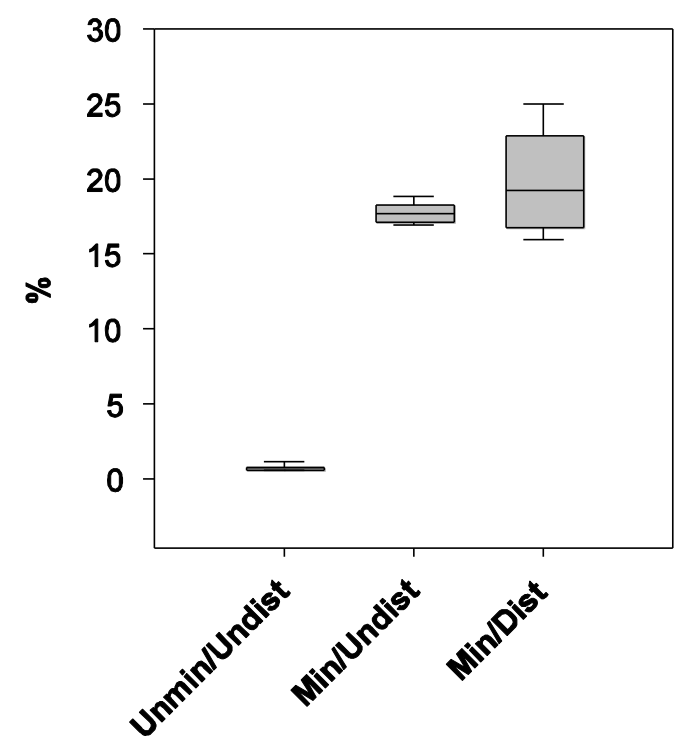

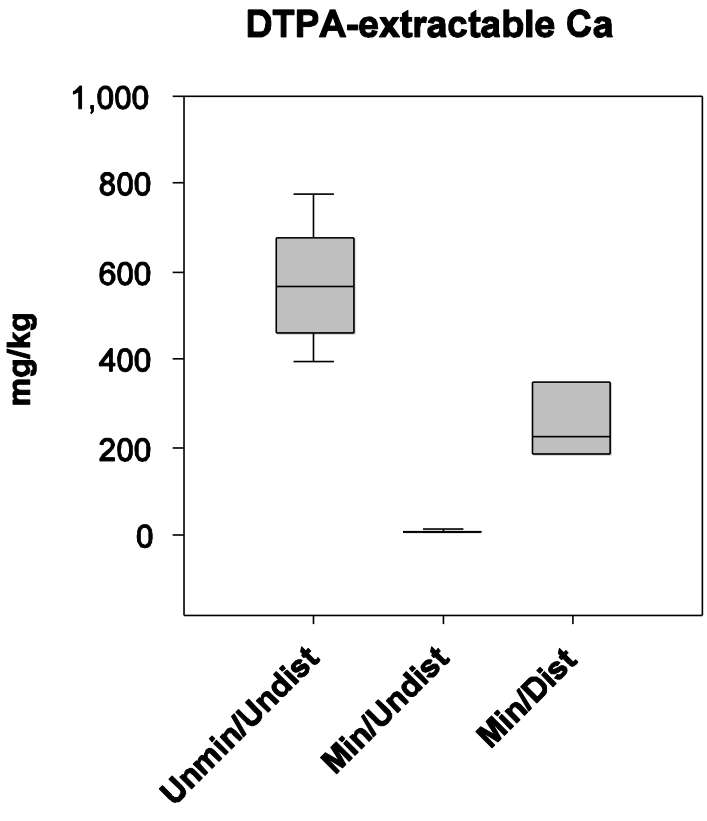

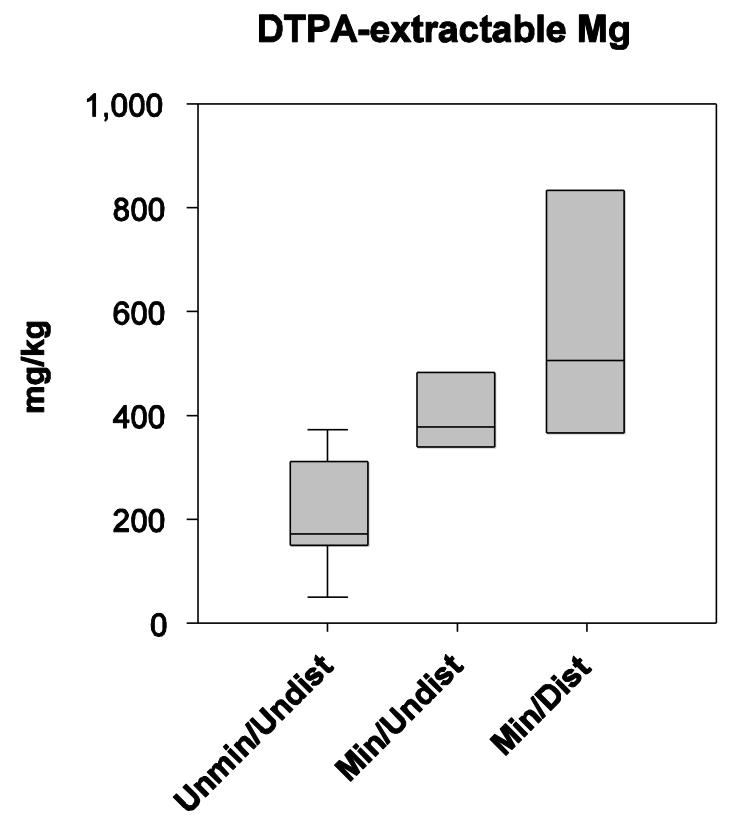

Figure 9. Red Hills study area, Tuolumne County, Calif.: Selected soil macronutrient data (Total and DTPAextractable $\mathrm{Ca}$ and $\mathrm{Mg}$ ) across the study-design levels. Unmin/Undist, unmineralized/undisturbed (serpentinite soils); Min/Undist, mineralized/undisturbed (andesite soils); Min/Dist, mineralized/disturbed (waste-rock and tailings piles). 
Total soil $\mathbf{P}$

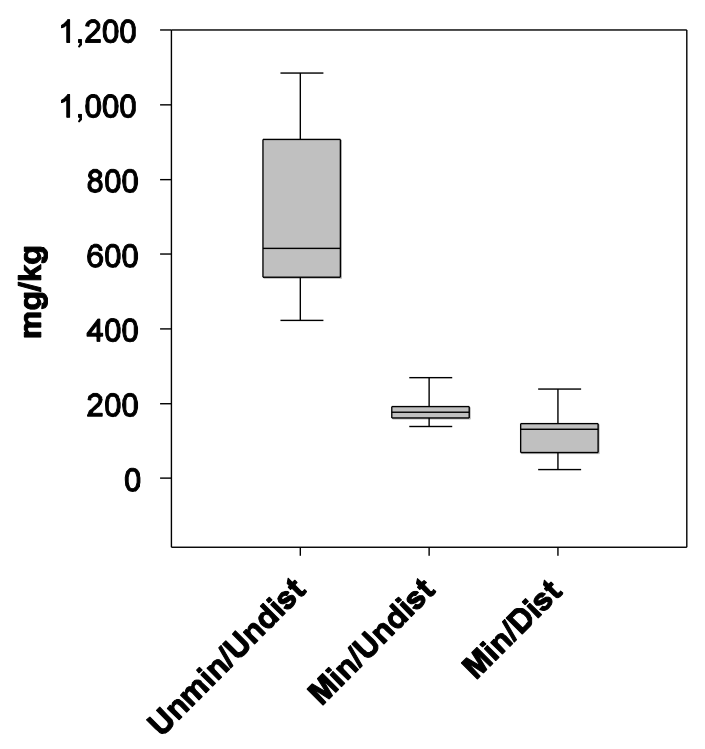

DTPA-extractable P

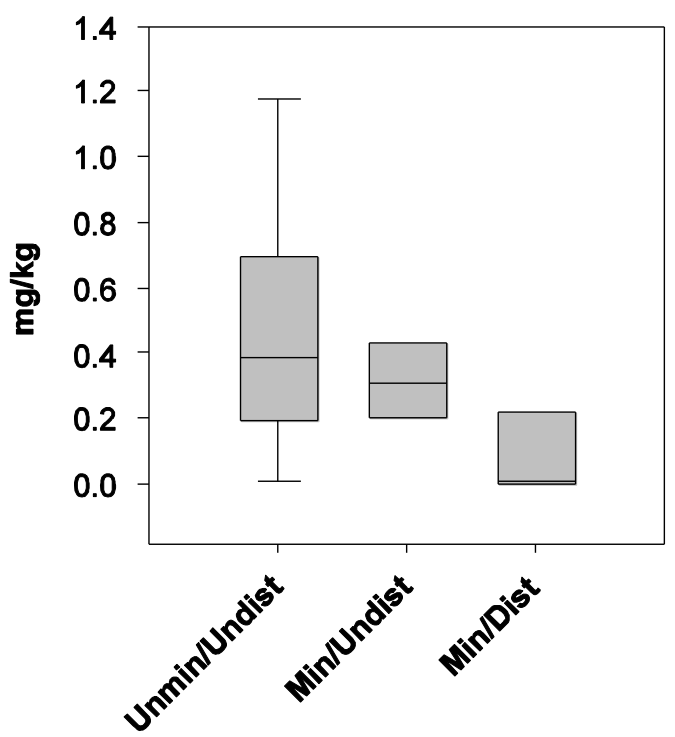

Figure 10. Red Hills study area, Tuolumne County, Calif.: Selected soil macronutrient data (Total and DTPAextractable P) across the study-design levels. Unmin/Undist, unmineralized/undisturbed (serpentinite soils); Min/Undist, mineralized/undisturbed (andesite soils); Min/Dist, mineralized/disturbed (waste-rock and tailings piles). 
Total soil Ni

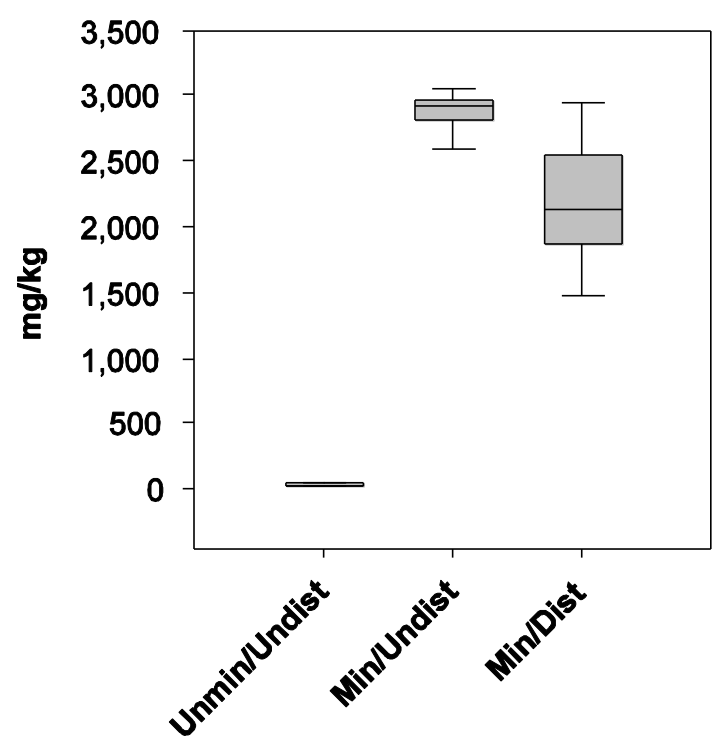

Total soil $\mathbf{C r}$

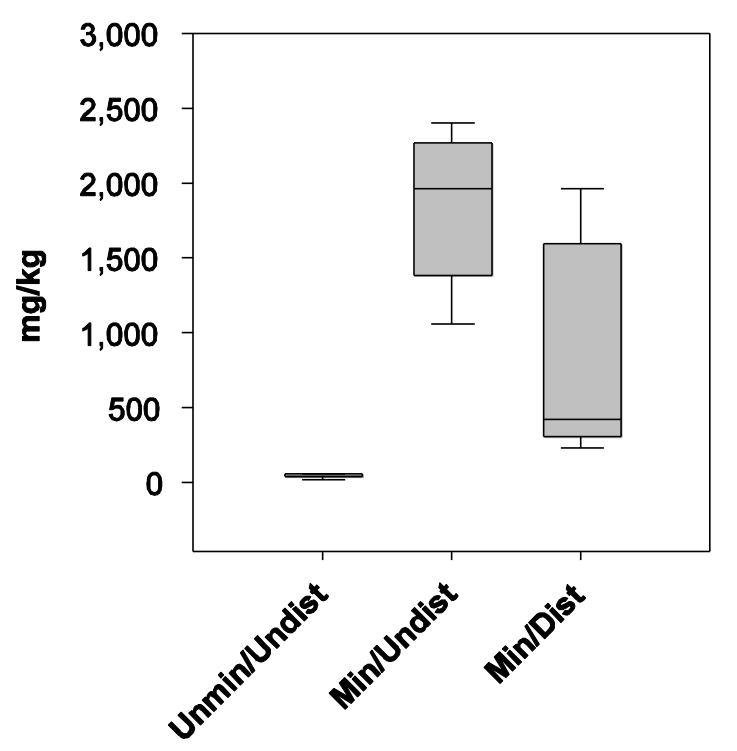

DTPA-extractable Ni

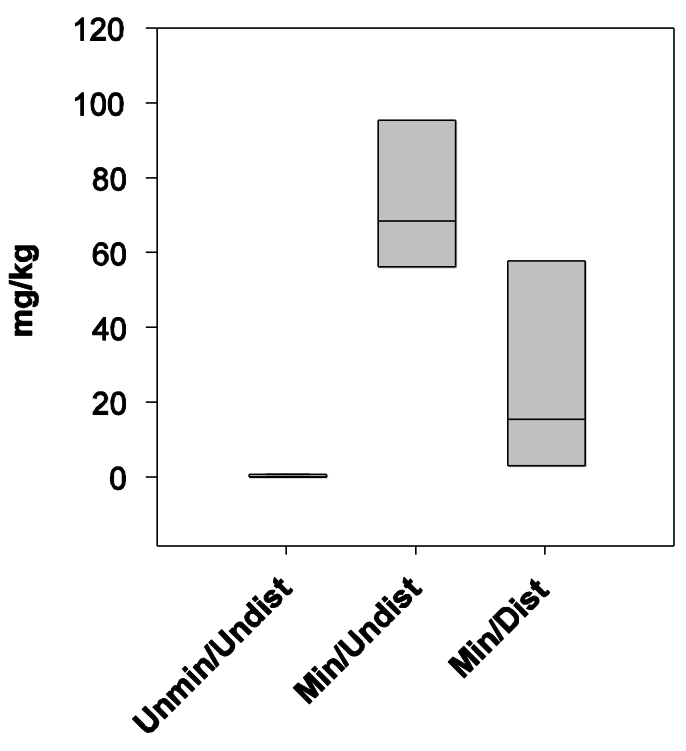

DTPA-extractable $\mathrm{Cr}$

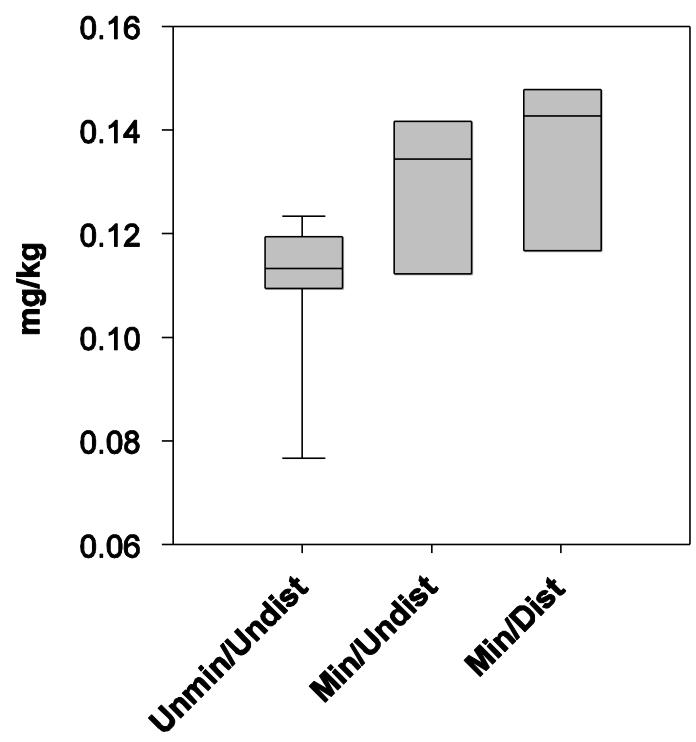

Figure 11. Red Hills study area, Tuolumne County, Calif.: Selected soil trace metals (Total and DTPA-extractable $\mathrm{Ni}$ and $\mathrm{Cr}$ ) across the study-design levels. Unmin/Undist, unmineralized/undisturbed (serpentinite soils); Min/Undist, mineralized/undisturbed (andesite soils); Min/Dist, mineralized/disturbed (waste-rock and tailings piles). 

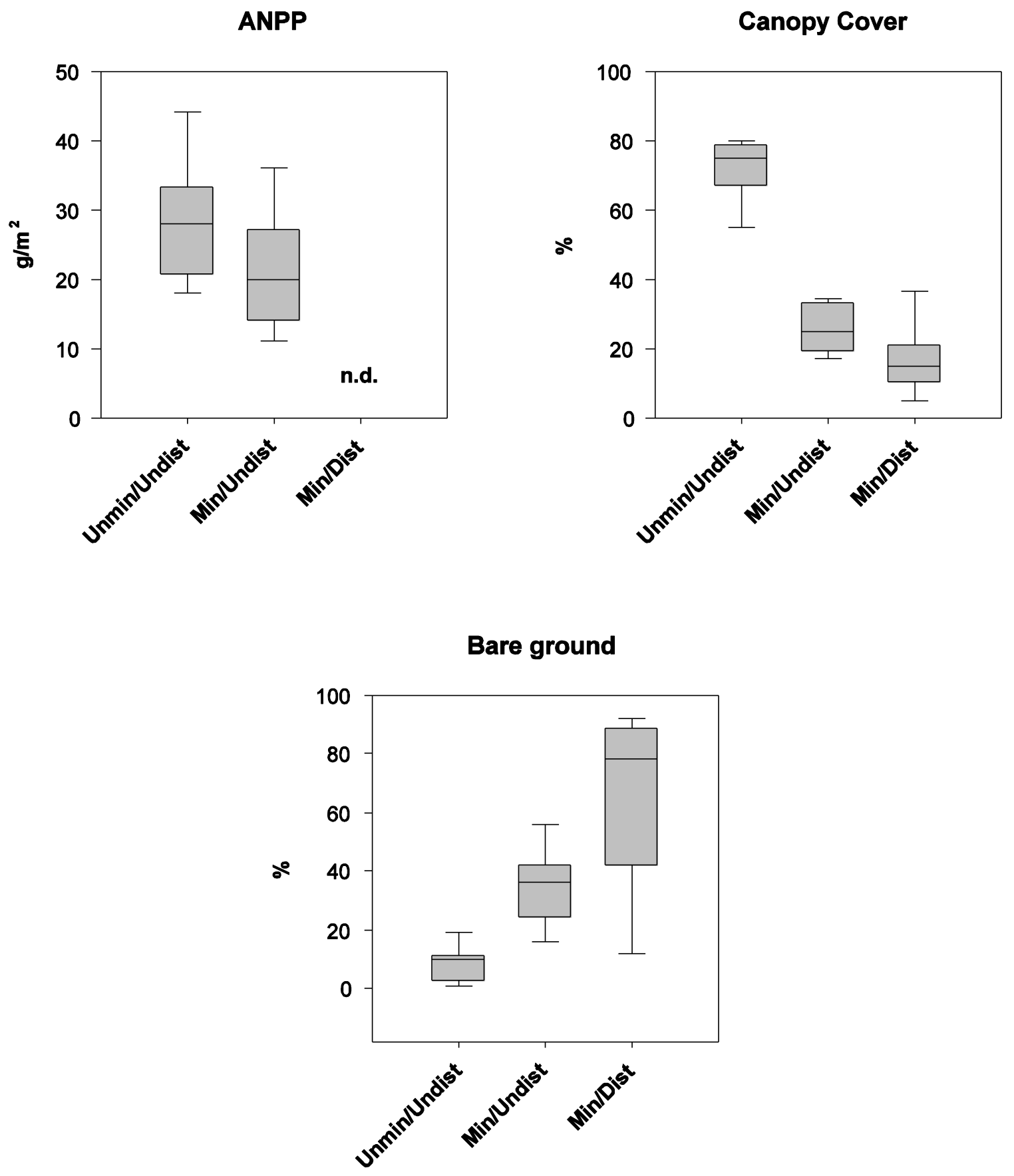

Figure 12. Red Hills study area, Tuolumne County, Calif.: Selected vegetation data (Aboveground net primary productivity (ANPP), Canopy cover, Bare ground) across the study-design levels. Unmin/Undist, unmineralized/undisturbed (serpentinite soils); Min/Undist, mineralized/undisturbed (andesite soils); Min/Dist, mineralized/disturbed (waste-rock and tailings piles); n.d., not determined. 

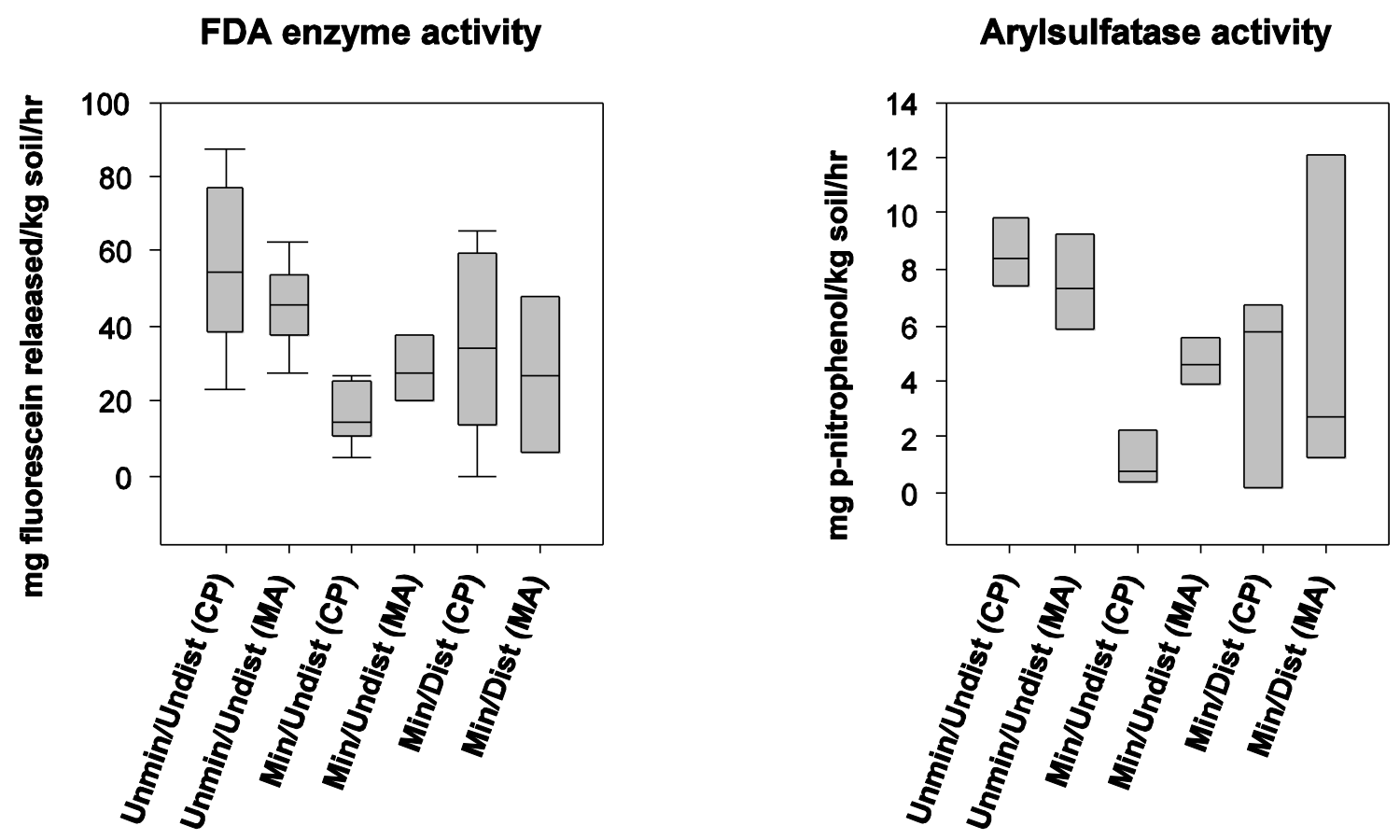

Acid phosphatase activity
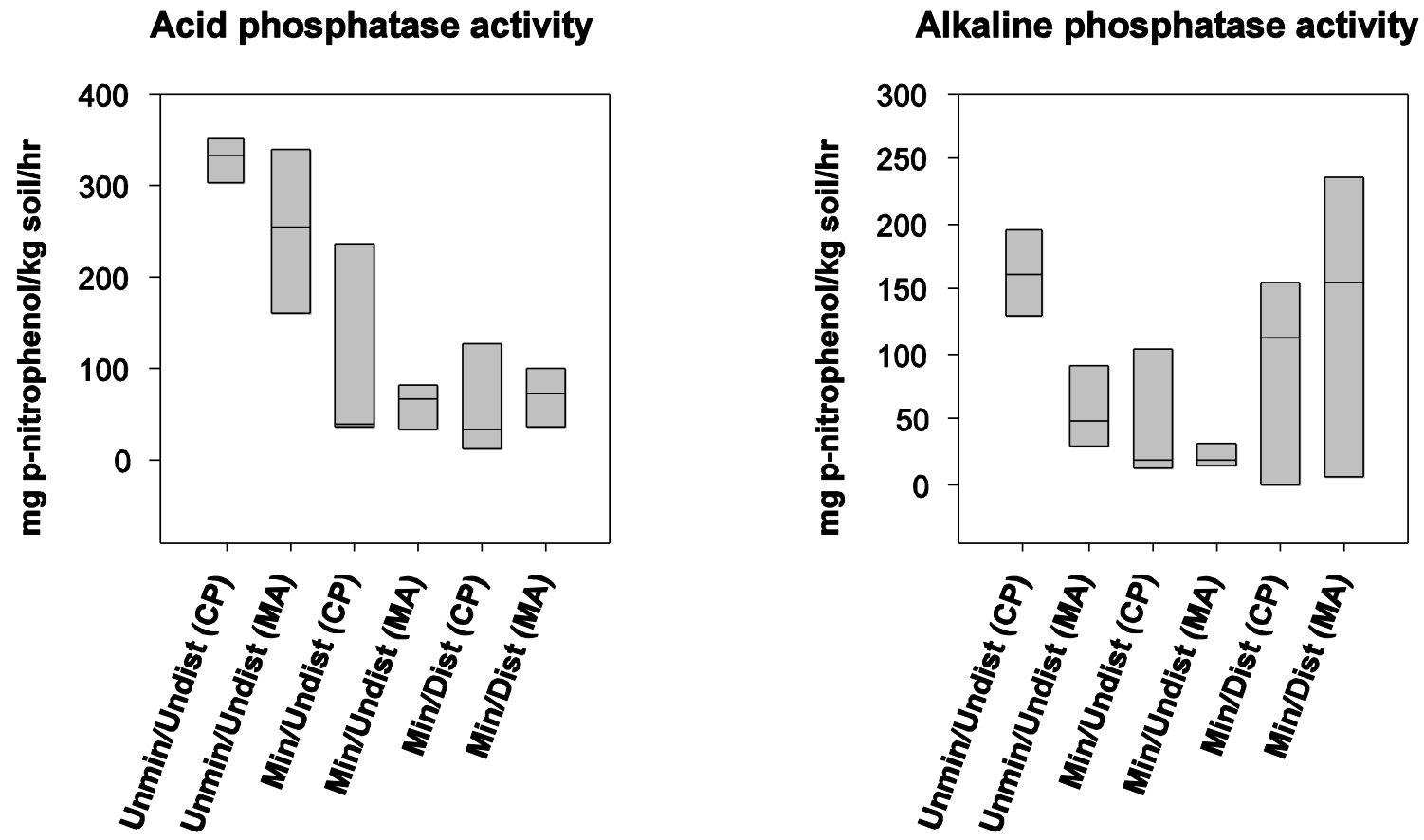

Figure 13. Quartz-alunite study sites: Soil microbial data (Enzyme activity) across the study-design levels. Unmin/Undist, unmineralized/undisturbed (andesite soils); Min/Undist, mineralized/undisturbed (quartz-alunite soils); Min/Dist, mineralized/disturbed (waste-rock and tailings piles), CP, Castle Peak; MA, Masonic; FDA, Fluorescein diacetate. 
Potentially mineralizable C

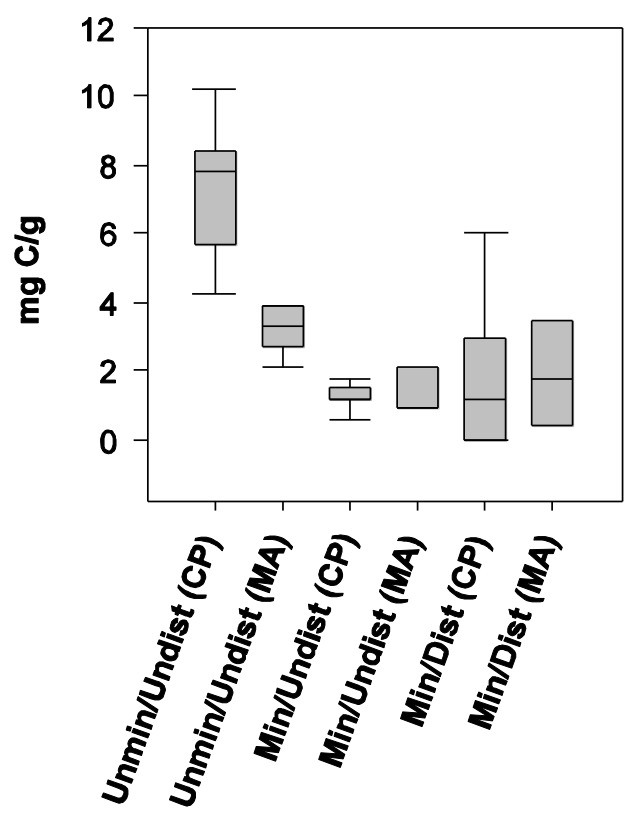

Soil organic C (\%)

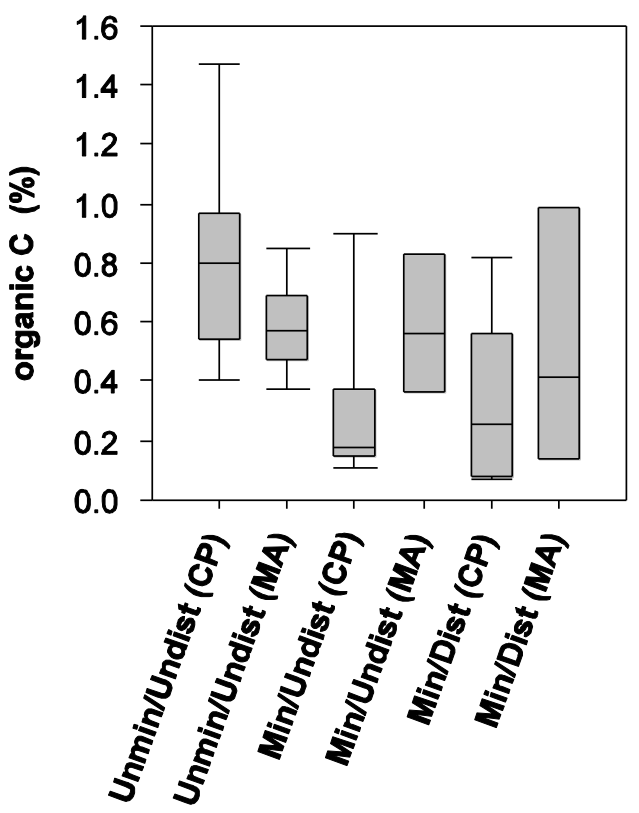

Potentially mineralizable $\mathbf{N}$

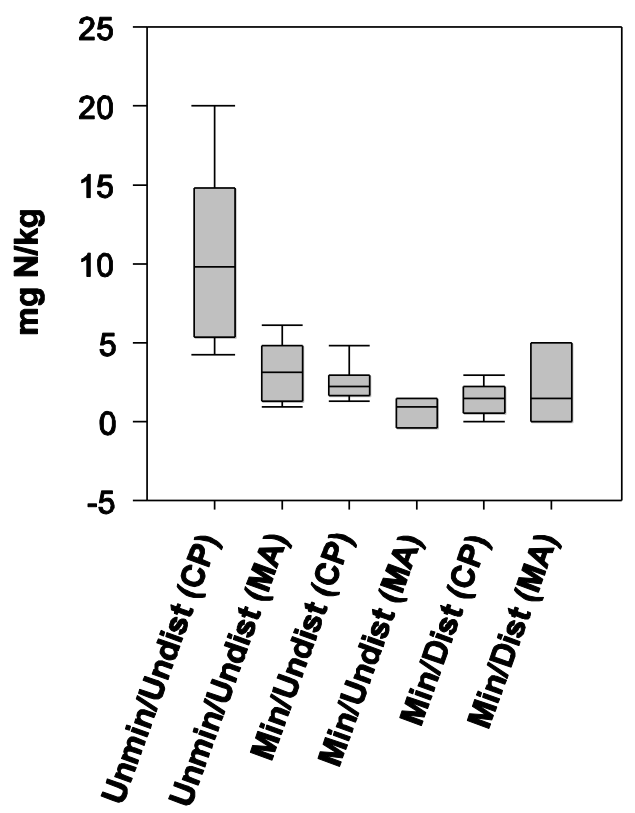

Total Soil N (\%)

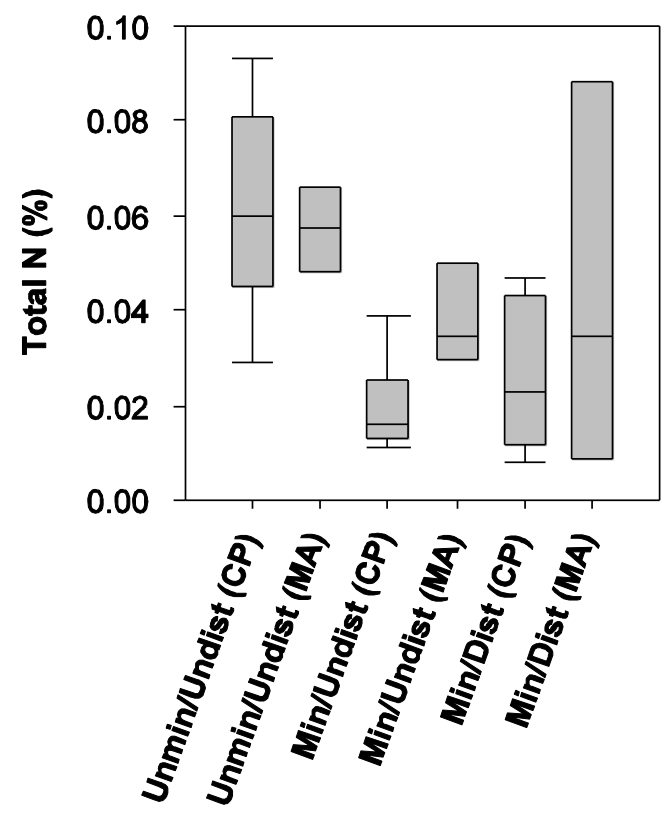

Figure 14. Quartz-alunite study sites: Soil microbial data (Mineralizeable $\mathrm{C}$ and N, Organic C, and Total N) across the study-design levels. Unmin/Undist, unmineralized/undisturbed (andesite soils); Min/Undist, mineralized/undisturbed (quartz-alunite soils); Min/Dist, mineralized/disturbed (waste-rock and tailings piles); CP, Castle Peak; MA, Masonic. 
Ecoplate: AWCD (Day 4)

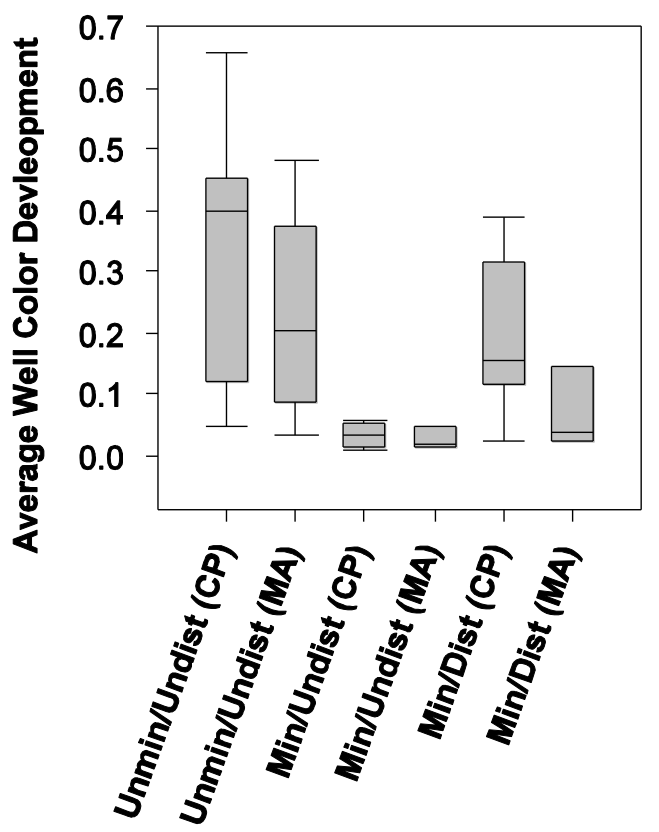

Microbial biomass (PLFA)

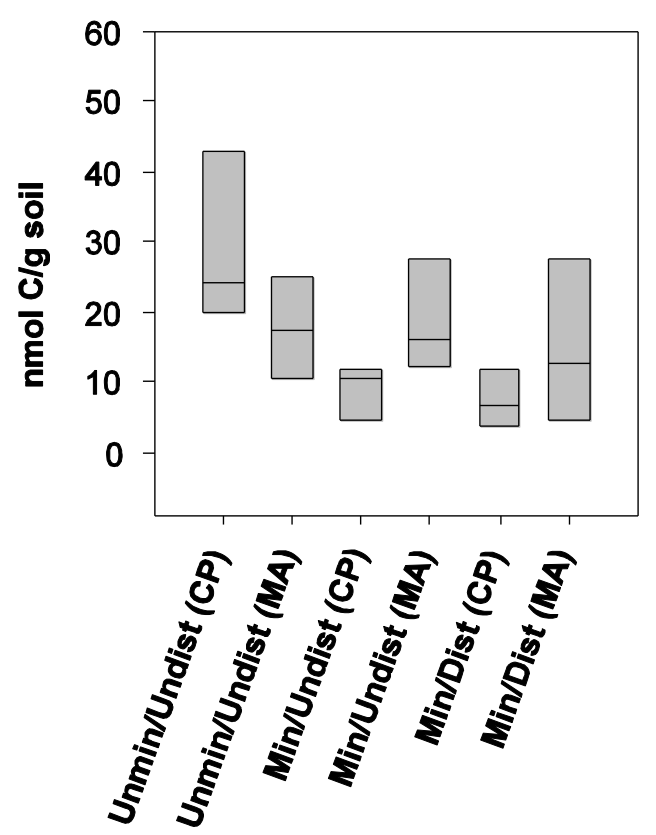

Figure 15. Quartz-alunite study sites: Soil microbial data (Ecoplate AWCD, Microbial biomass (PLFA)) across the study-design levels. Unmin/Undist, unmineralized/undisturbed (andesite soils); Min/Undist, mineralized/undisturbed (quartz-alunite soils); Min/Dist, mineralized/disturbed (waste-rock and tailings piles); CP, Castle Peak; MA, Masonic; AWCD, average well color development; PLFA, Phospholipid fatty acids. 


\section{Soil pH}

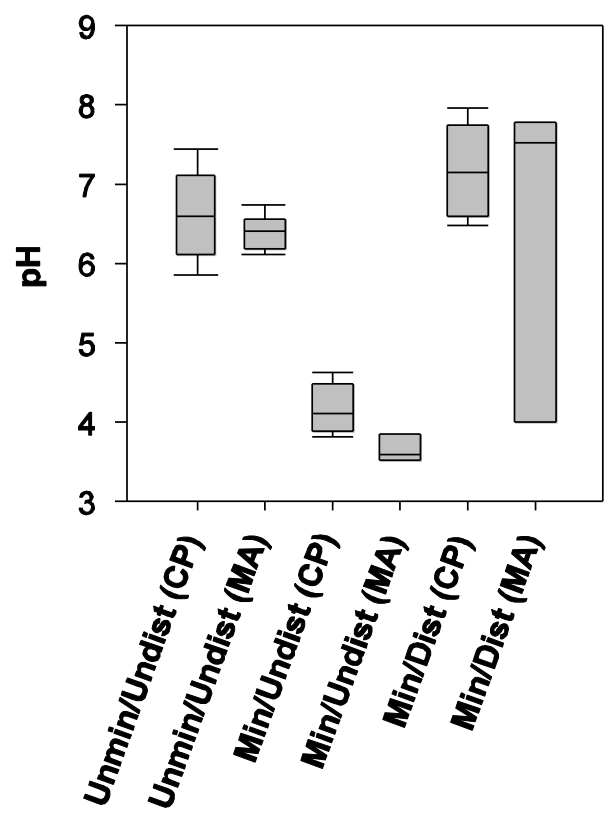

Water-filled pore space (\%)

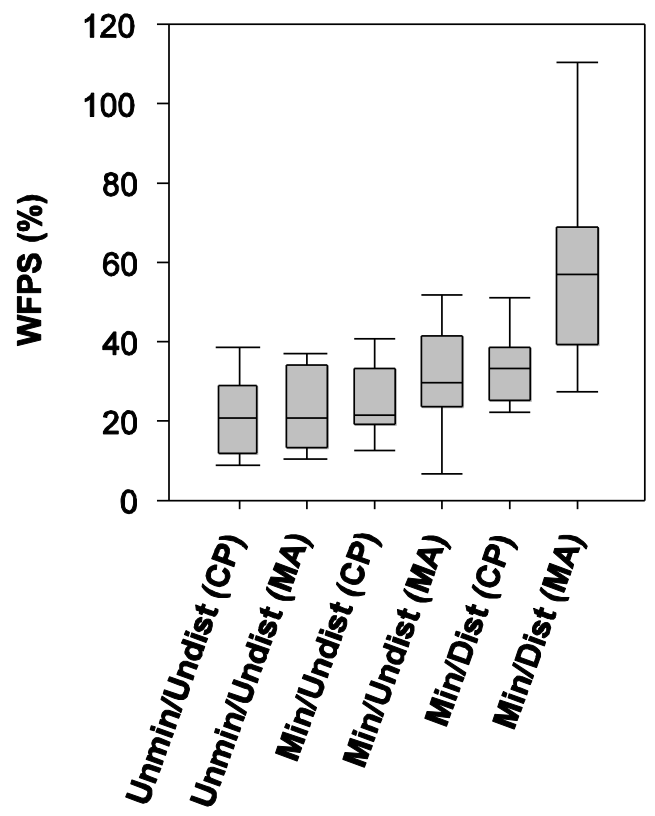

Electrical conductivity (EC)

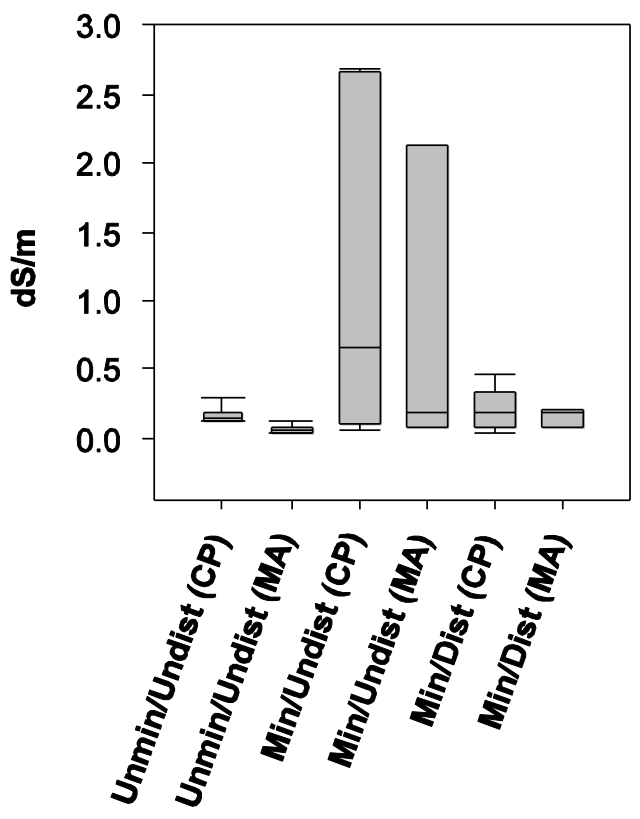

Bulk density

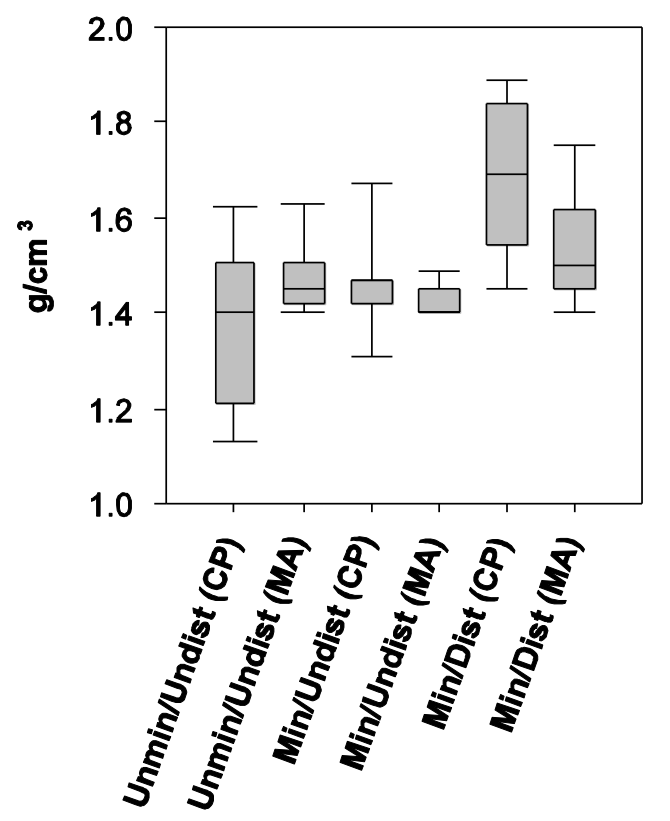

Figure 16. Quartz-alunite study sites: Selected soil chemical and physical data (Soil pH, Electrical conductivity, Water-filled pore space (WFPS), Bulk density) across the study-design levels. Unmin/Undist, unmineralized/undisturbed (andesite soils); Min/Undist, mineralized/undisturbed (quartz-alunite soils); Min/Dist, mineralized/disturbed (waste-rock and tailings piles); CP, Castle Peak; MA, Masonic; $d S=$ decisiemens. 
Total Soil-P

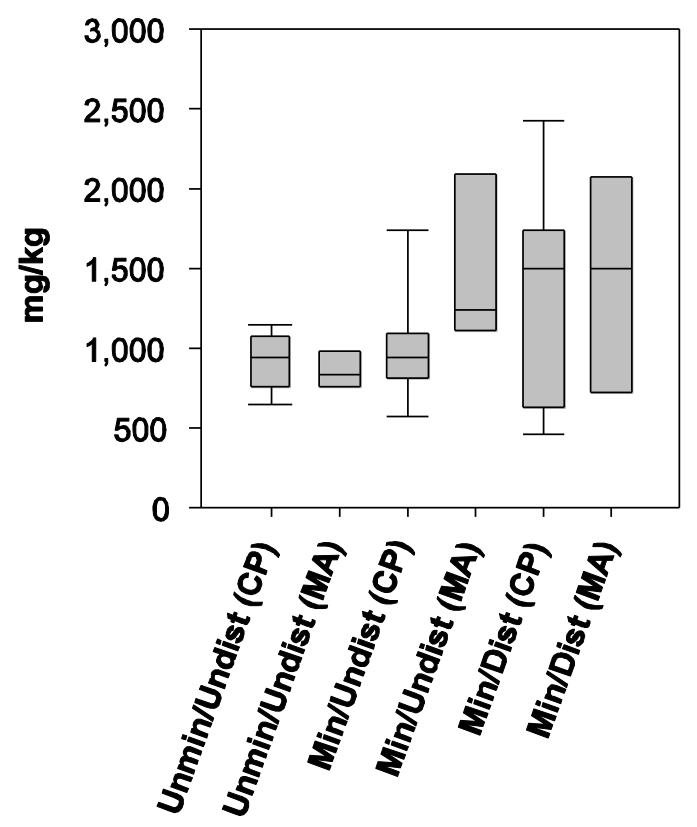

Water-soluble soil-P

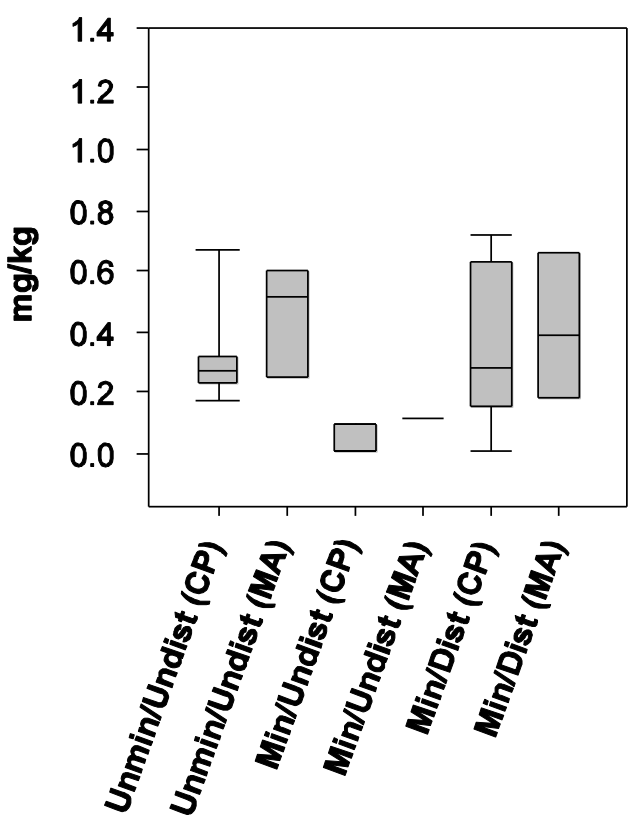

\section{Inorganic Soil-N (NO3 + NH4)}

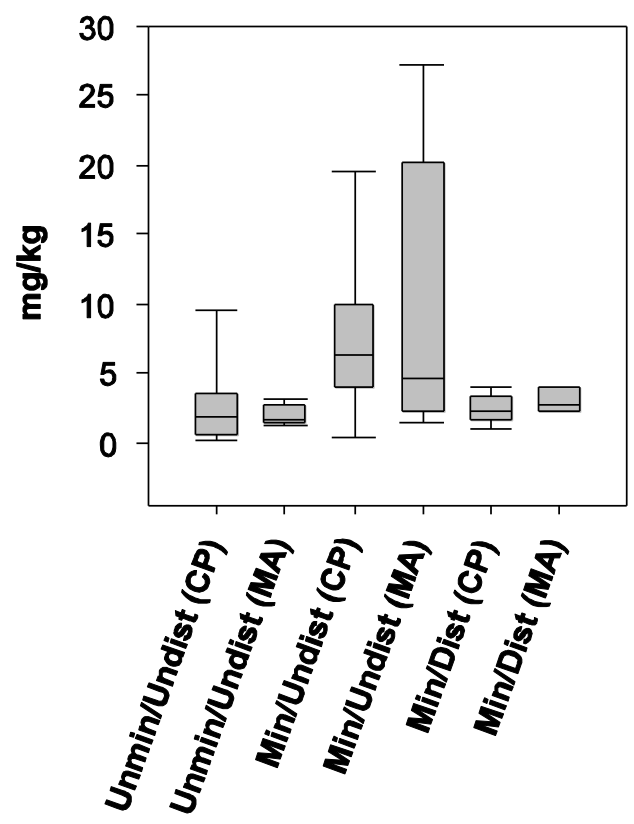

Figure 17. Quartz-alunite study sites: Selected soil macronutrient data (Total and Water-soluble P, and Inorganic N) across the study-design levels. Unmin/Undist, unmineralized/undisturbed (andesite soils); Min/Undist, mineralized/undisturbed (quartz-alunite soils); Min/Dist, mineralized/disturbed (waste-rock and tailings piles); NO3, nitrate; $\mathrm{NH} 4$, ammonium; $\mathrm{CP}$, Castle Peak; MA, Masonic. 
Total Soil-S
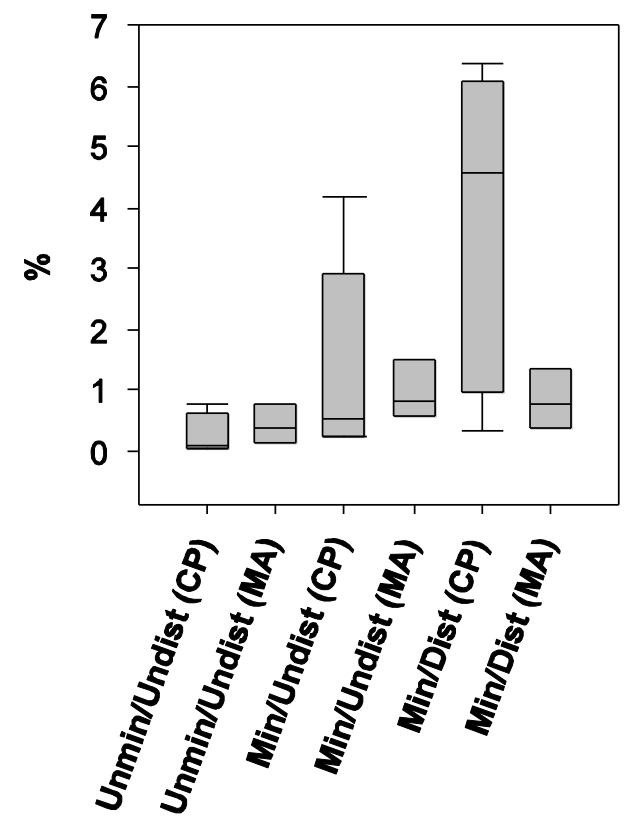

Total Soil-Mg

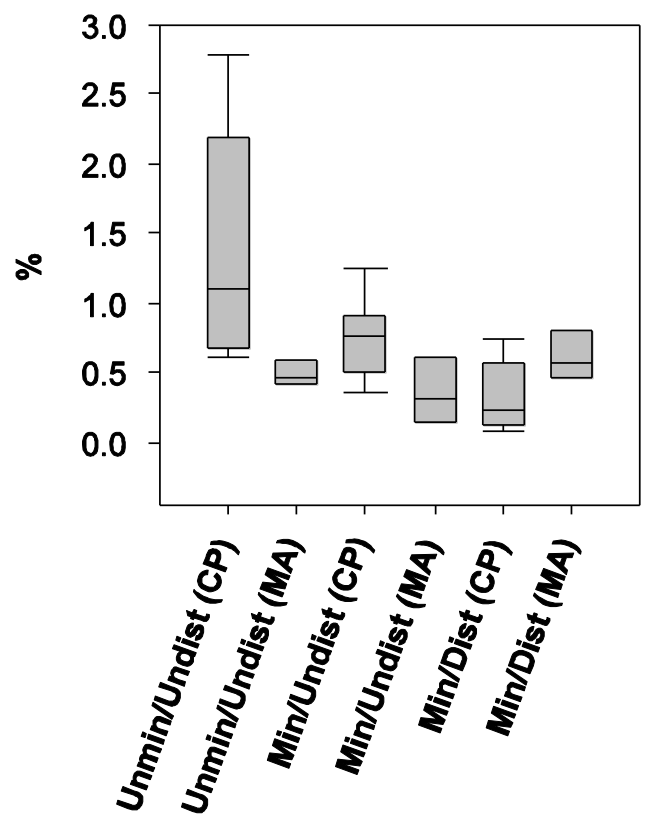

DTPA-extractable SO4

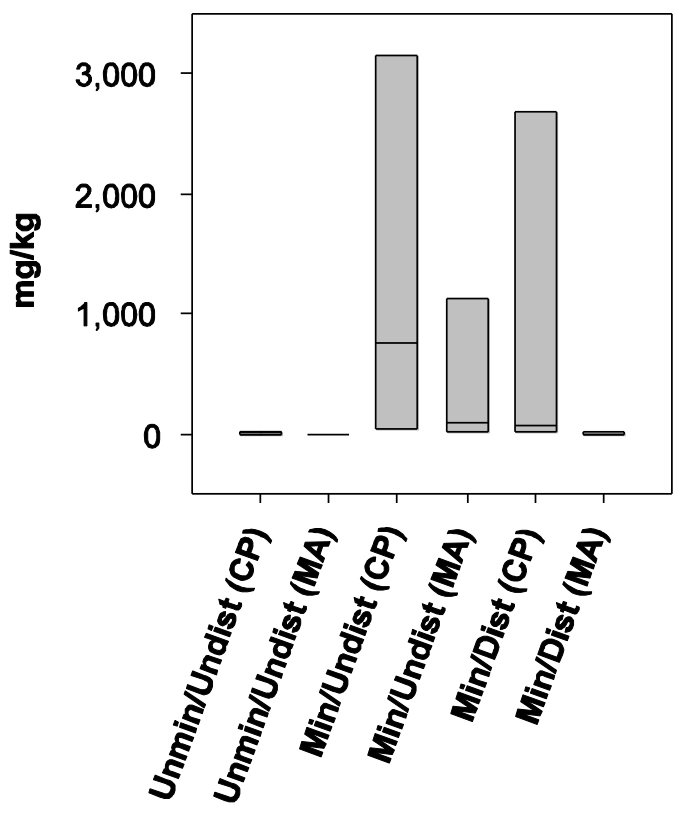

DTPA-extractable Mg

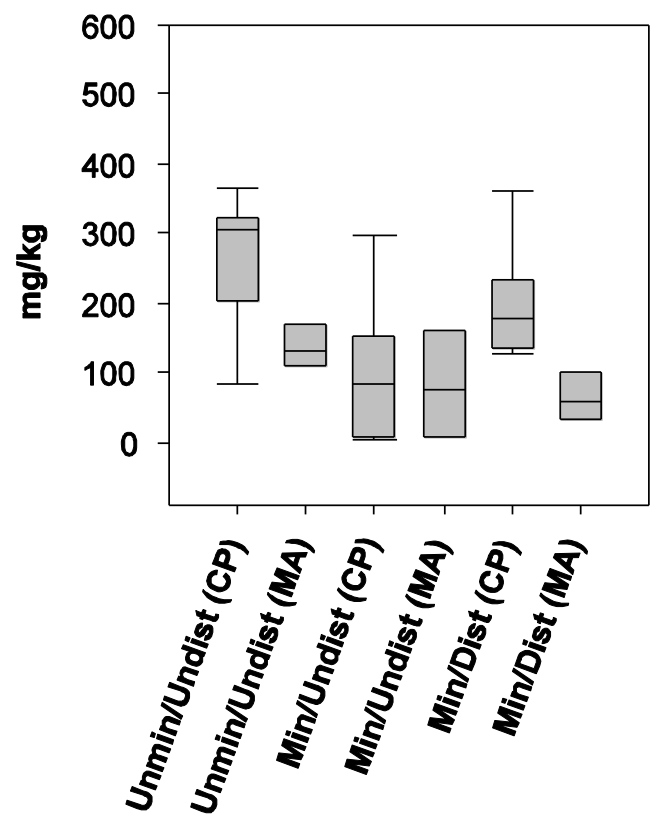

Figure 18. Quartz alunite study sites: Selected soil macronutrient data (Total and DTPA-extractable $S$ and $\mathrm{Mg}$ ) across the study-design levels. Unmin/Undist, unmineralized/undisturbed (andesite soils); Min/Undist, mineralized/undisturbed (quartz-alunite soils); Min/Dist, mineralized/disturbed (waste-rock and tailings piles); SO4, sulfate; CP, Castle Peak; MA, Masonic. 
Total Soil-Al

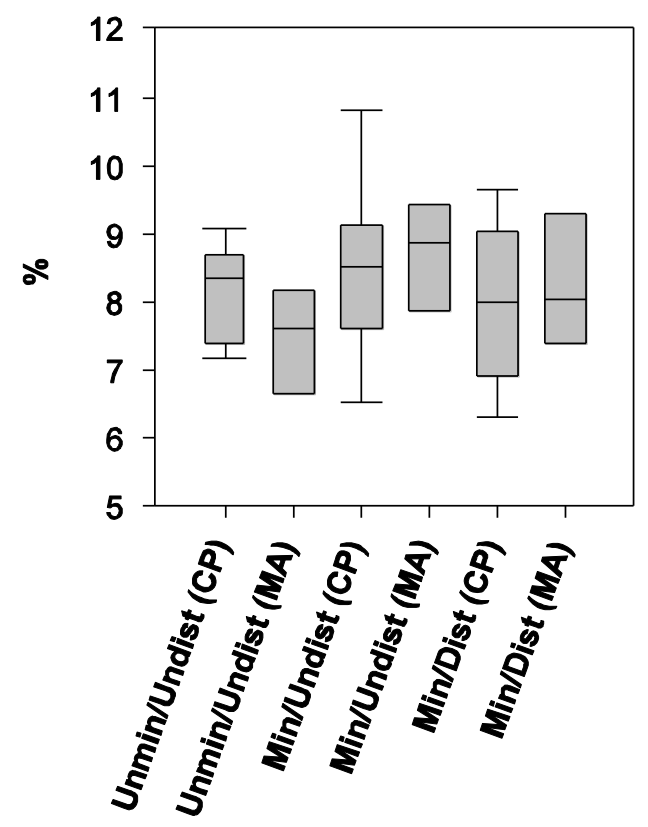

Total Soil-Pb

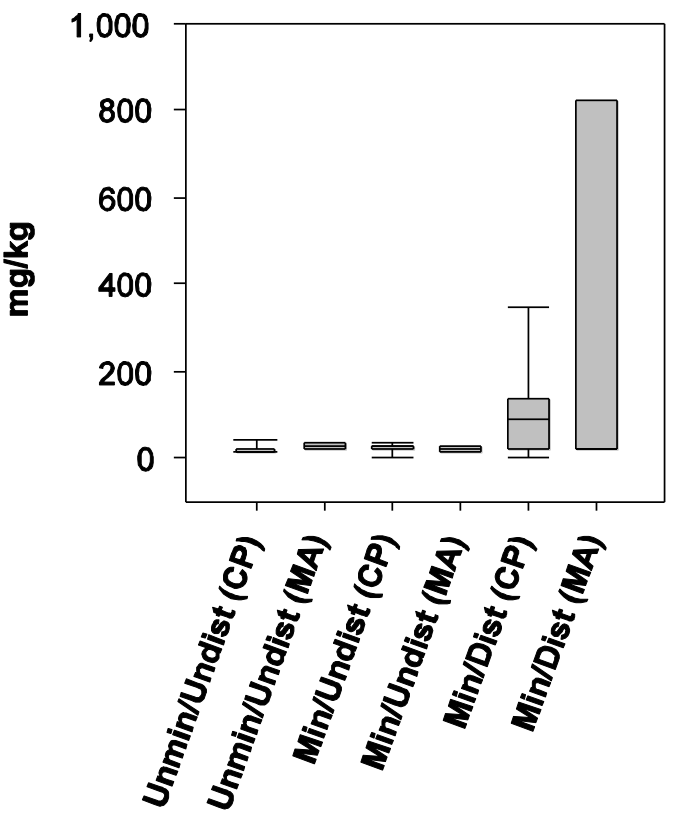

DTPA-extractable Al

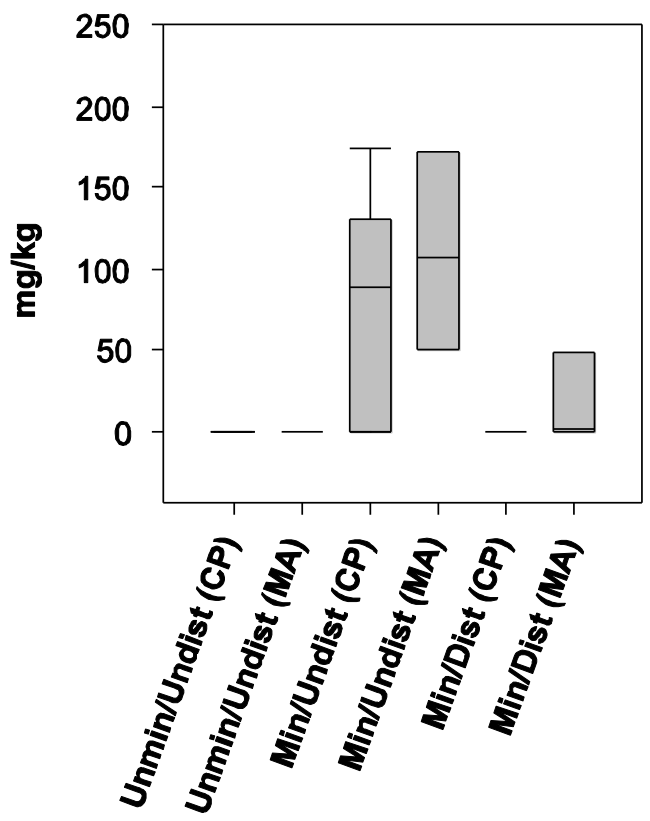

DTPA-extractable $\mathbf{P b}$

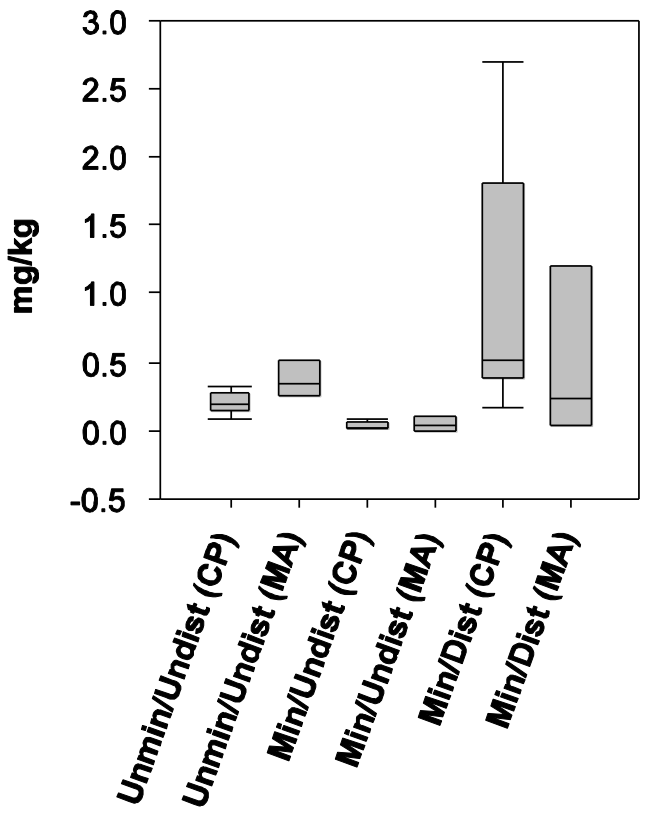

Figure 19. Quartz-alunite study sites: Selected soil metal data (Total and DTPA-extractable Al and Pb) across the study-design levels. Unmin/Undist, unmineralized/undisturbed (andesite soils); Min/Undist = mineralized/undisturbed (quartz-alunite soils); Min/Dist = mineralized/disturbed (waste-rock and tailings piles); CP, Castle Peak; MA, Masonic. 

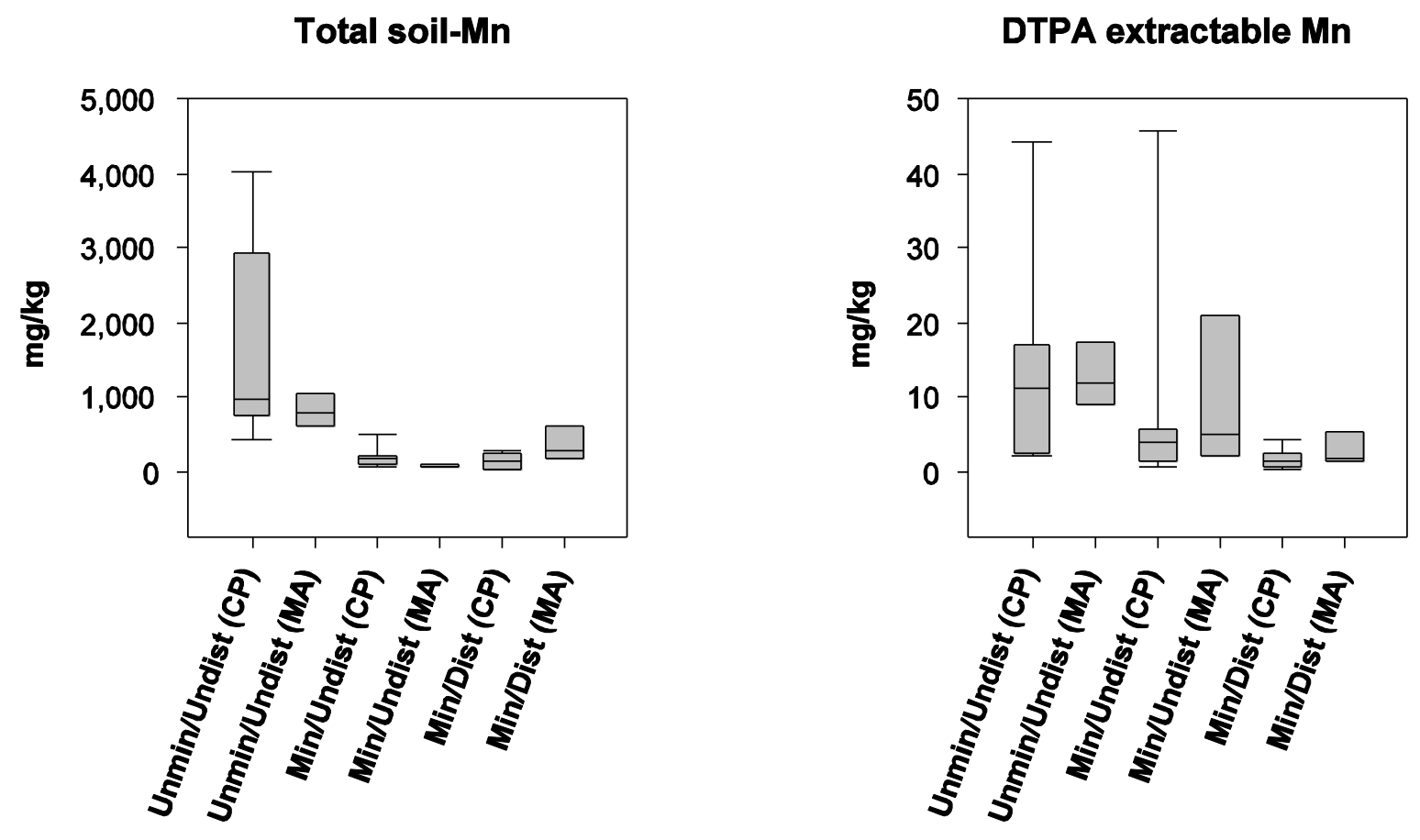

Total soil-Se

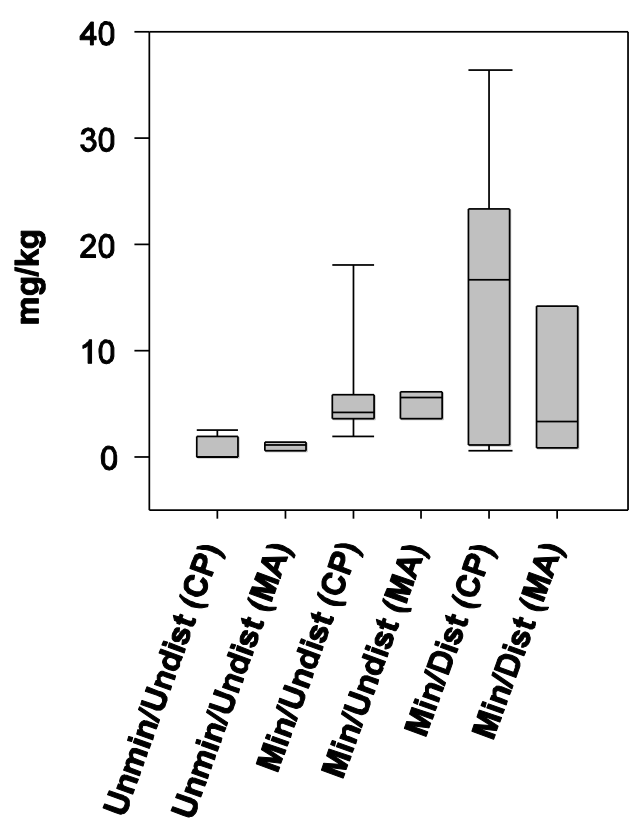

Figure 20. Quartz-alunite study sites: Selected soil metal data (Total and DTPA-extractable Mn and Total Se) across the study-design levels. Unmin/Undist = unmineralized/undisturbed (andesite soils); Min/Undist = mineralized/undisturbed (quartz-alunite soils); Min/Dist = mineralized/disturbed (waste-rock and tailings piles); CP, Castle Peak; MA, Masonic. 

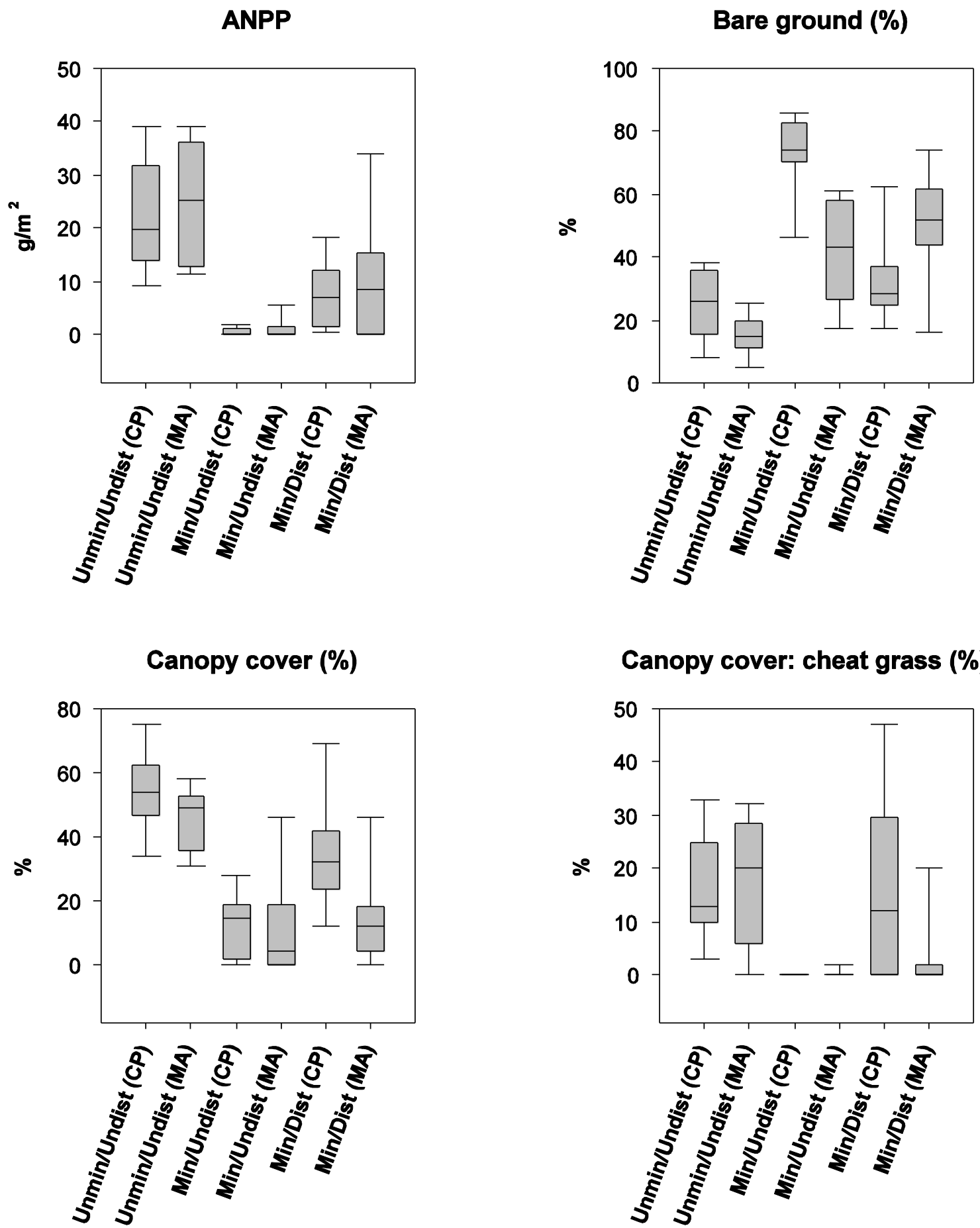

Canopy cover: cheat grass (\%)

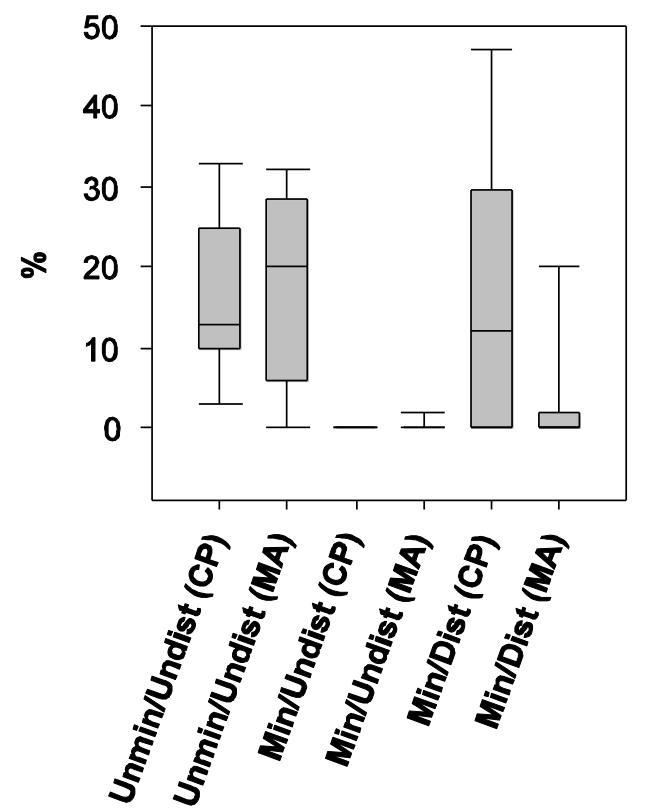

Figure 21. Quartz-alunite study sites: Selected vegetation data (Aboveground net primary productivity (ANPP), Bare ground, Canopy cover, Canopy cover comprised of cheat grass) across the study-design levels. Unmin/Undist, unmineralized/undisturbed (andesite soils); Min/Undist, mineralized/undisturbed (quartz-alunite soils); Min/Dist = mineralized/disturbed (waste-rock and tailings piles); CP, Castle Peak; MA, Masonic. 

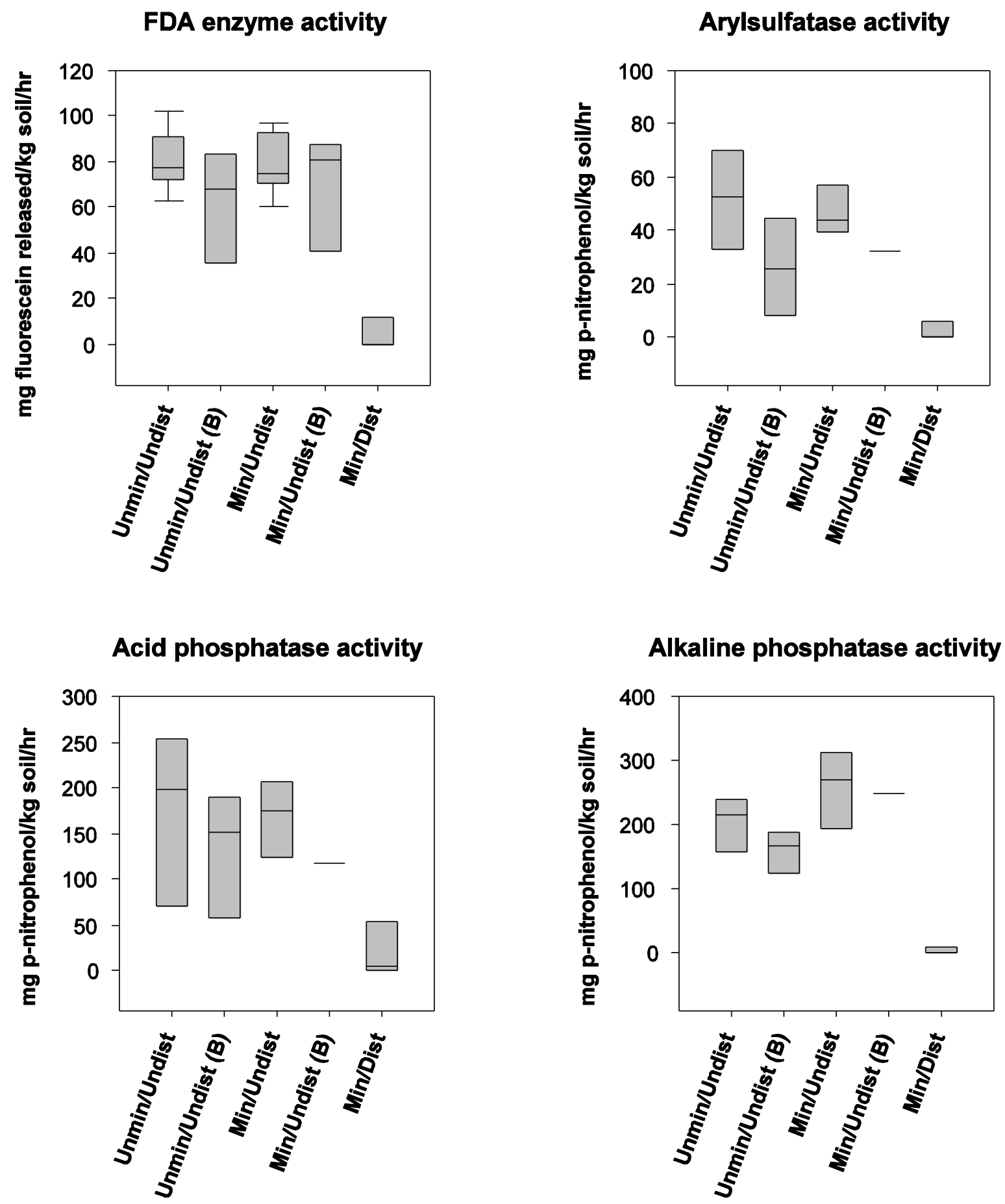

Figure 22. Buckingham study area, north-central, Nevada: Soil microbial data (Enzyme activity) across the studydesign levels. Unmin/Undist, unmineralized/undisturbed soils; Min/Undist, mineralized/undisturbed soils; Min/Dist, mineralized/disturbed (waste-rock and tailings piles); (B), samples taken between shrub canopies (Min/Dist samples were also taken between shrub canopies); FDA, Fluorescein diacetate. 

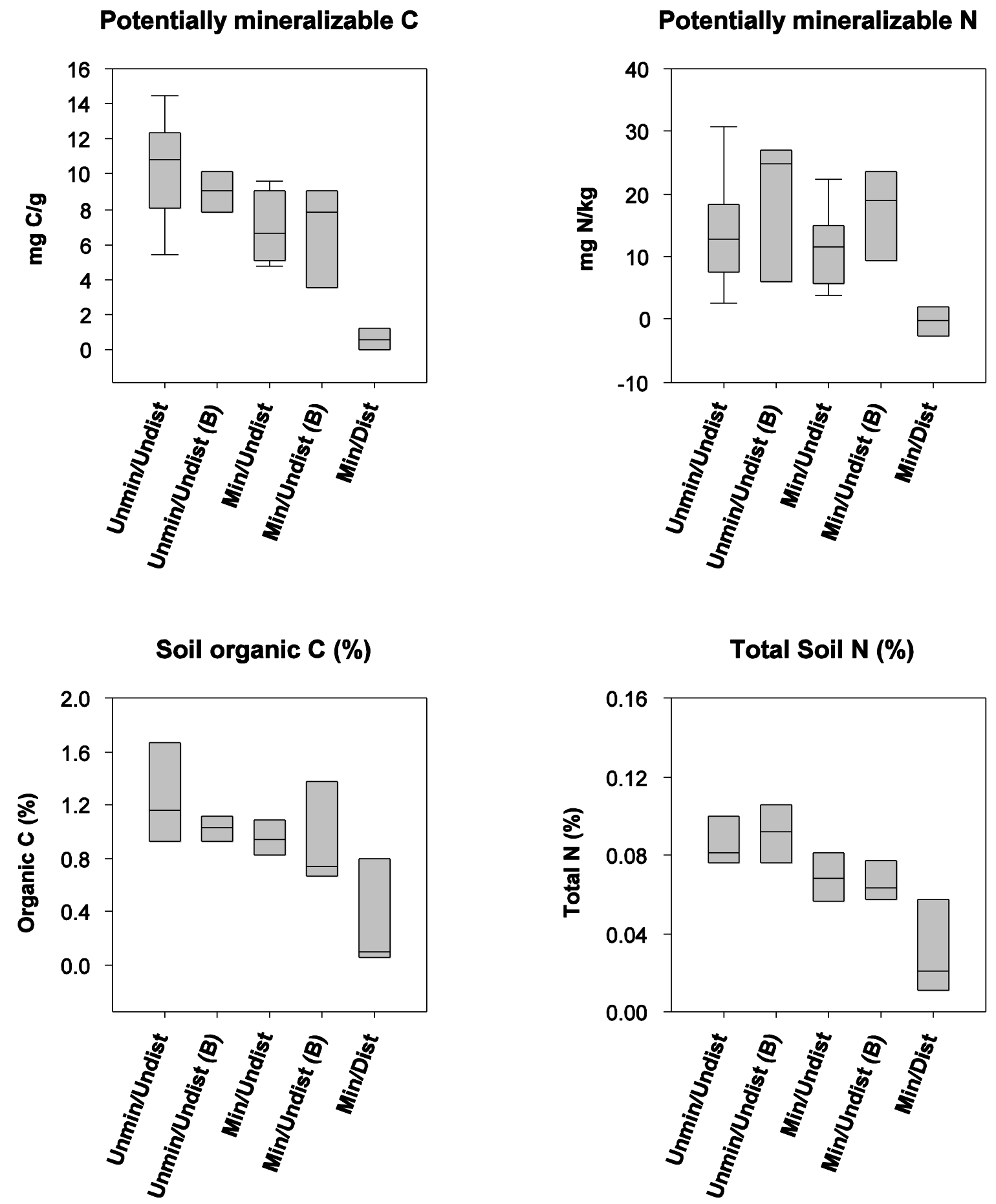

Figure 23. Buckingham study area, north-central, Nevada: Soil microbial data (Mineralizeable C and N, Organic C, Total N) across the study-design levels. Unmin/Undist, unmineralized/undisturbed soils; Min/Undist, mineralized/undisturbed soils; Min/Dist, mineralized/disturbed (waste-rock and tailings piles); (B), samples taken between shrub canopies (Min/Dist samples were also taken between shrub canopies). 
Ecoplate: AWCD (Day 4)

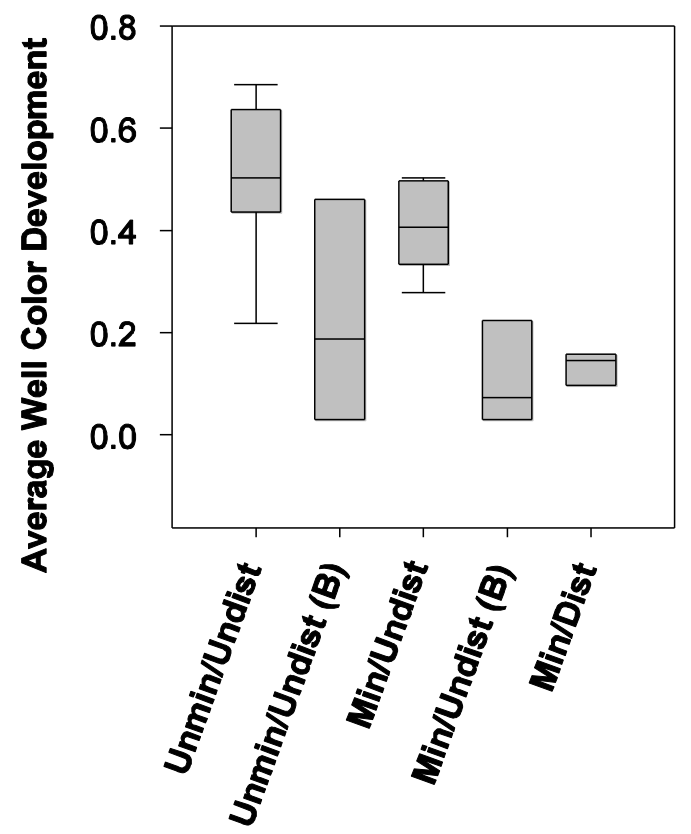

Microbial biomass (PLFA)

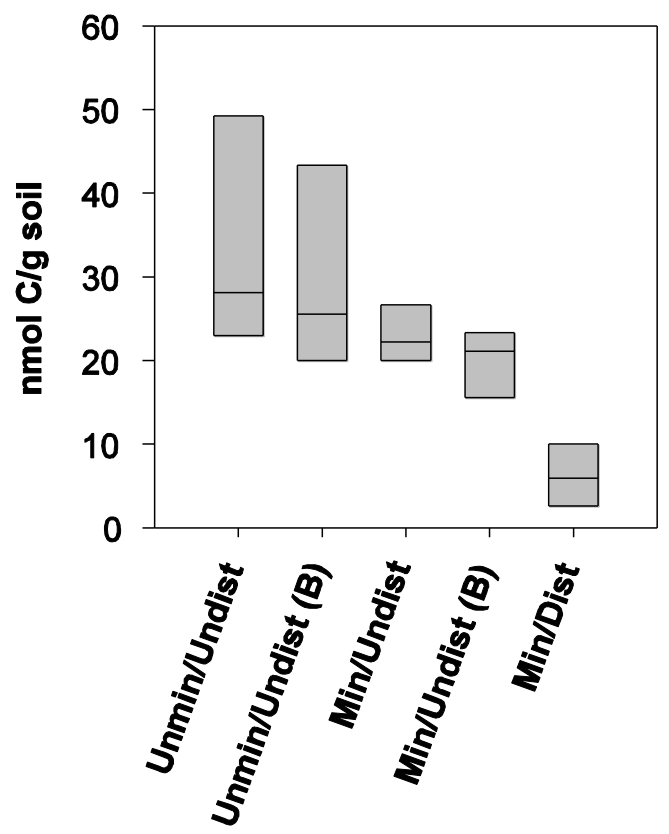

Figure 24. Buckingham study area, north-central, Nevada: Soil microbial data (Ecoplate AWCD, Microbial biomass (PLFA)) across the study-design levels. Unmin/undist, unmineralized/undisturbed soils; Min/Undist, mineralized/undisturbed soils; Min/Dist, mineralized/disturbed (waste-rock and tailings piles). (B), samples taken between shrub canopies (Min/Dist samples were also taken between shrub canopies); AWCD, Average well color development; PLFA, Phospholipid fatty acids. 


\section{Soil pH}

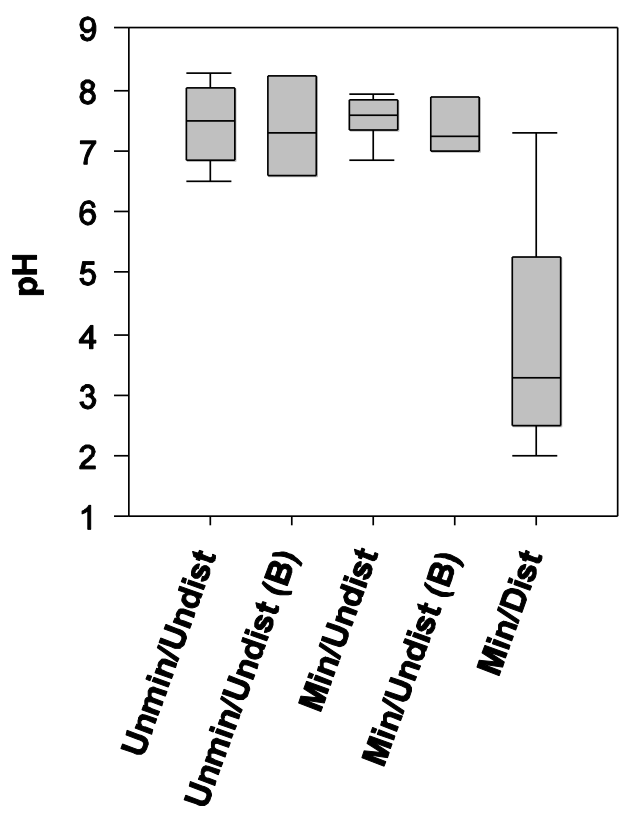

Water-filled pore space (\%)

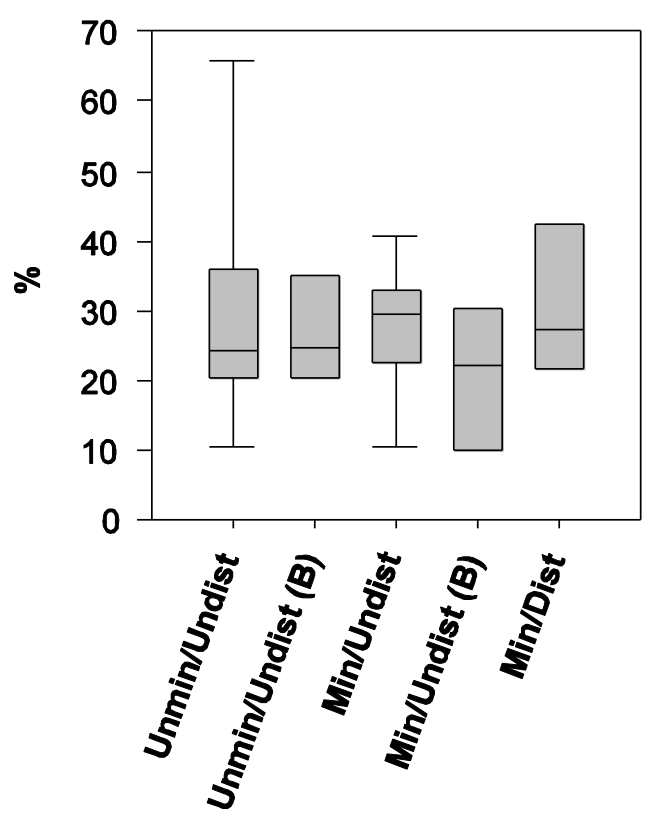

Electrical conductivity (EC)

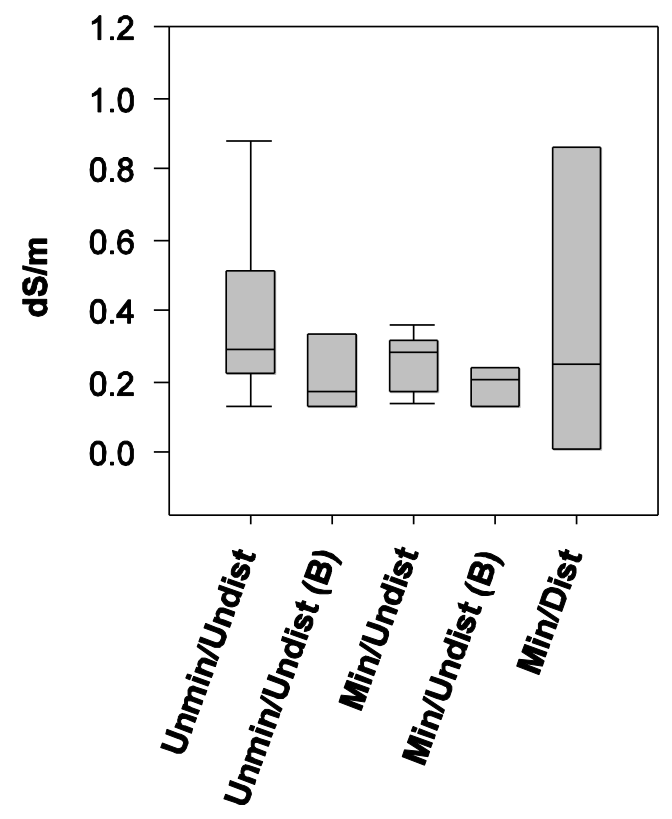

Bulk density

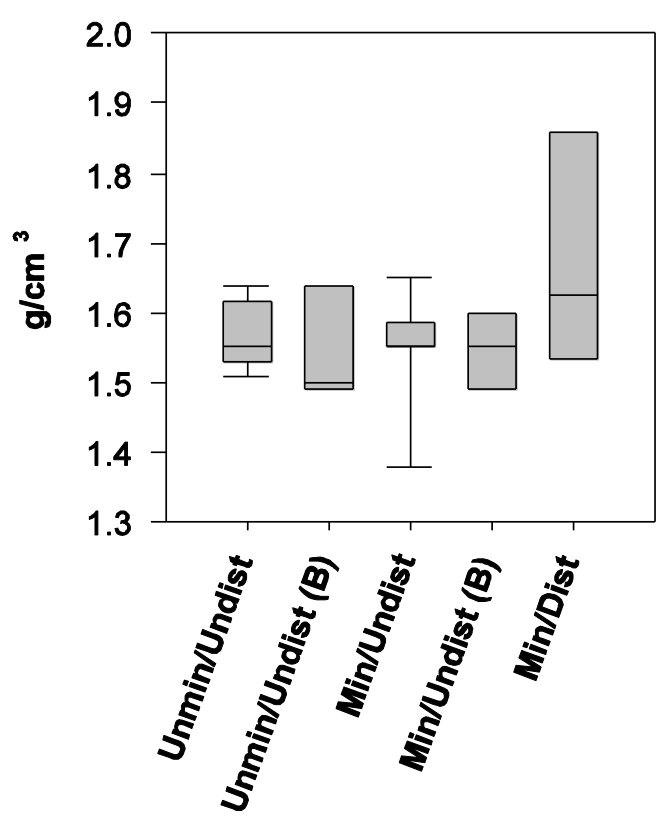

Figure 25. Buckingham study area, north-central, Nevada: Selected soil chemical and physical data (Soil pH, Electrical conductivity, Water-filled pore space (WFPS), Bulk density) across the study-design levels. Unmin/Undist, unmineralized/undisturbed soils; Min/Undist, mineralized/undisturbed soils; Min/Dist, mineralized/disturbed (wasterock and tailings piles); (B), samples taken between shrub canopies (Min/Dist samples were also taken between shrub canopies); $\mathrm{dS}=$ decisiemens. 
Total soil-P

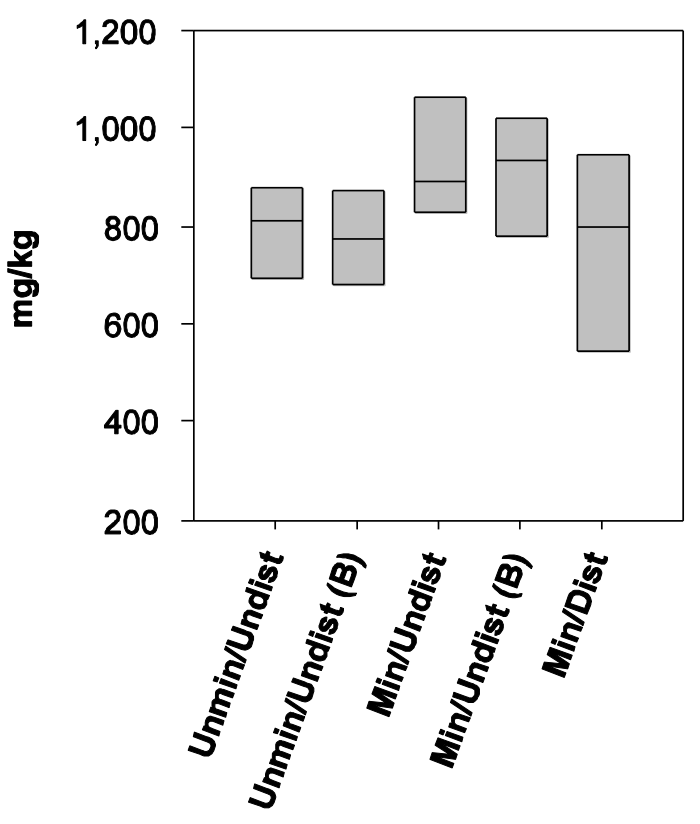

Water-soluble soil-P

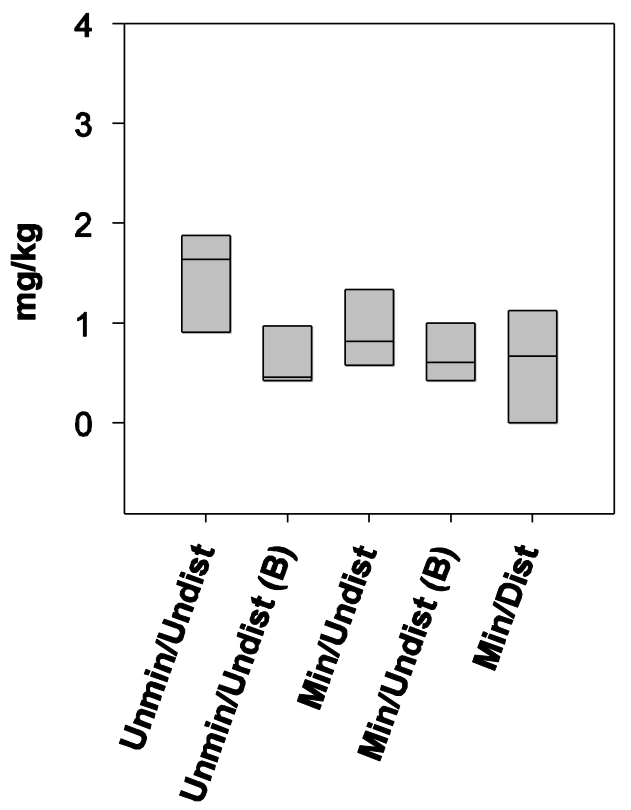

Inorganic soil-N (NO3 + NH4)

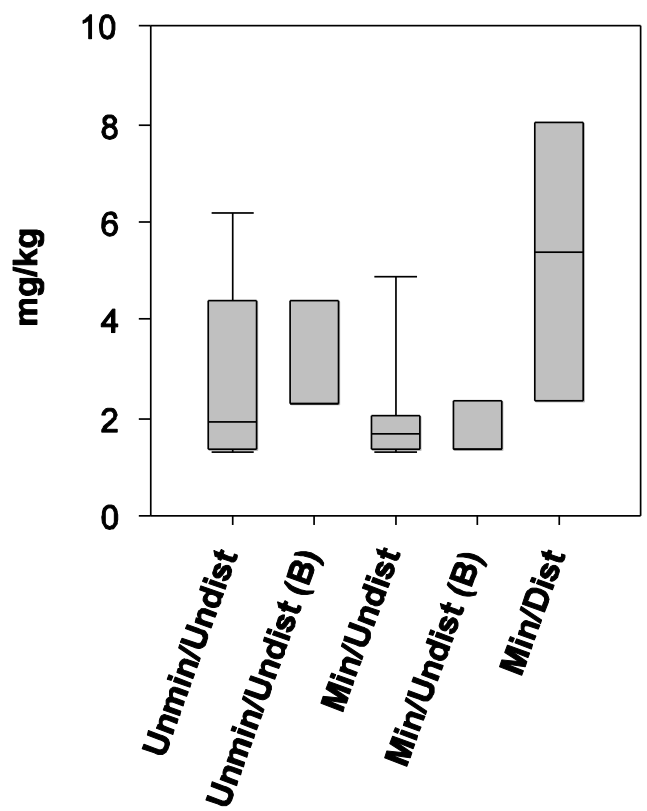

Figure 26. Buckingham study area, north-central, Nevada: Selected soil macronutrient data (Total and Watersoluble P, Inorganic N) across the study-design levels. Unmin/Undist, unmineralized/undisturbed soils; Min/Undist, mineralized/undisturbed soils; Min/Dist, mineralized/disturbed (waste-rock and tailings piles); (B), samples taken between shrub canopies (Min/Dist samples were also taken between shrub canopies); NO3, nitrate; NH4, ammonium. 
Total soil-S

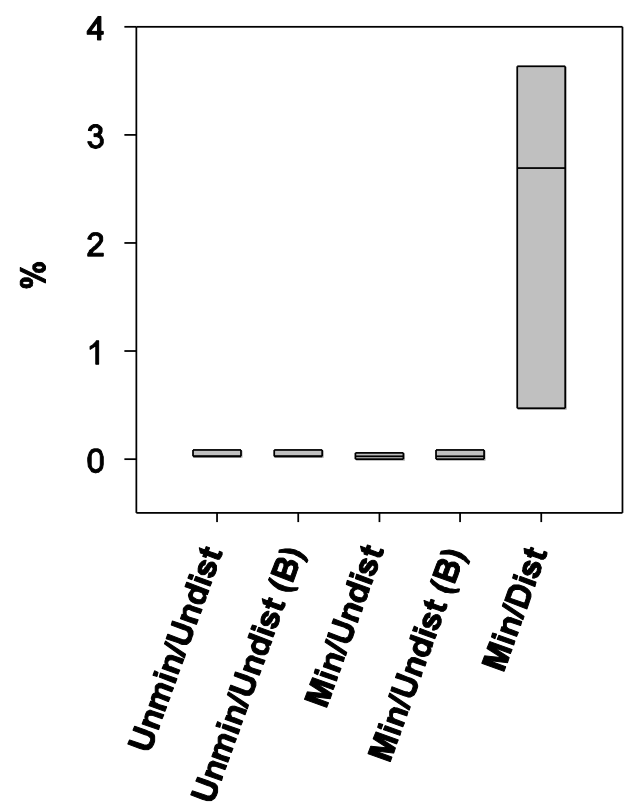

Total soil-Mg

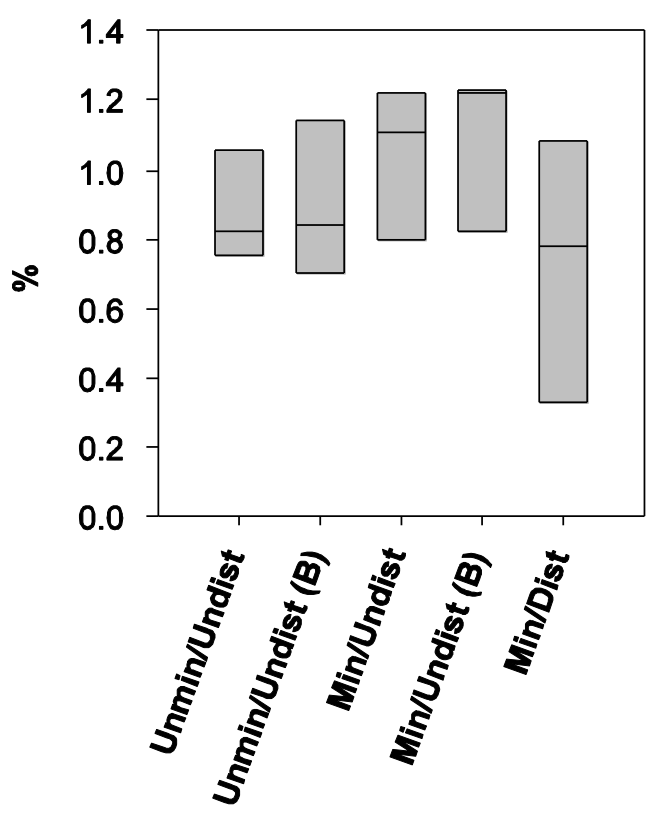

DTPA-extractable SO4

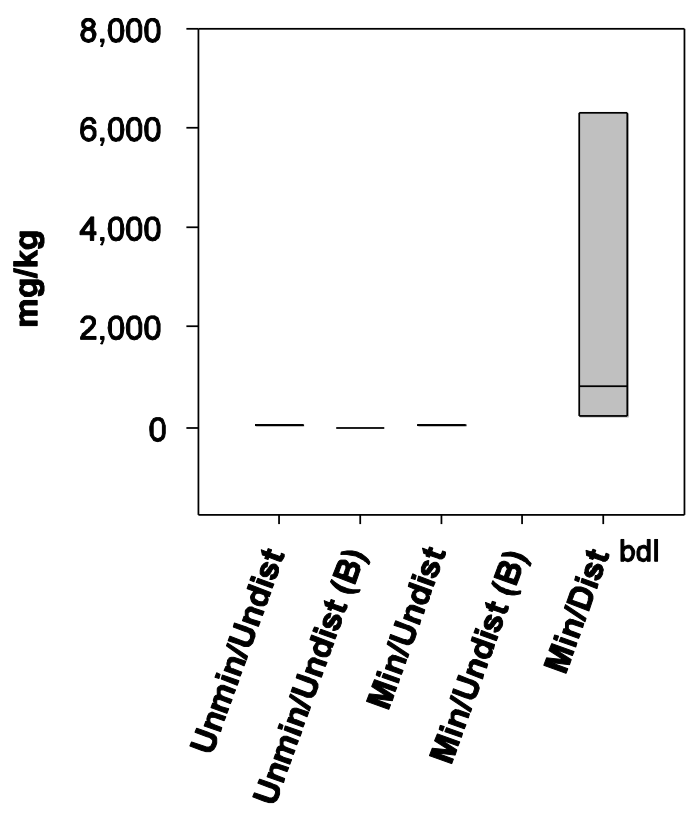

DTPA-extractable Mg

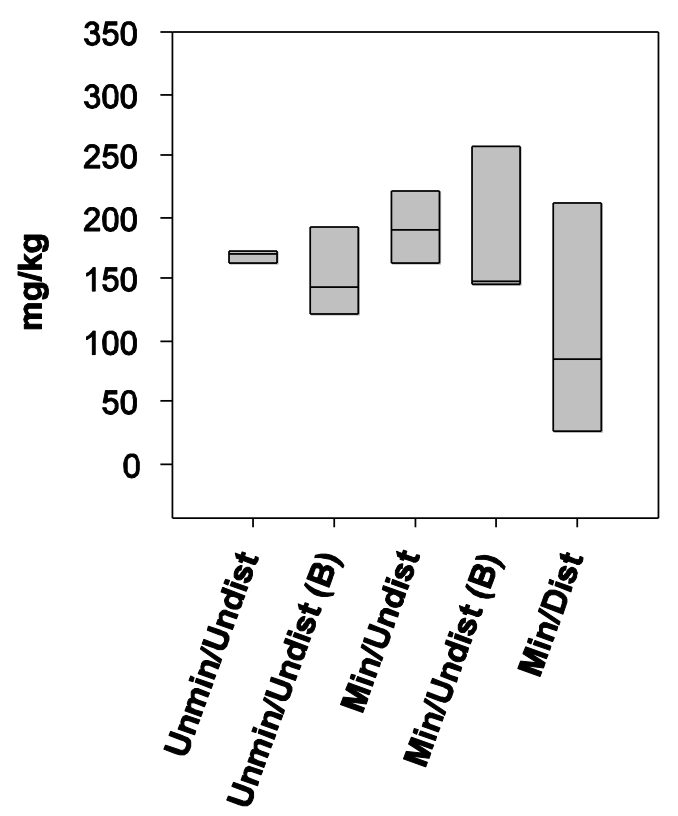

Figure 27. Buckingham study area, north-central, Nevada: Selected soil macronutrient data (Total and DTPAextractable $\mathrm{S}$ and $\mathrm{Mg}$ ) across the study-design levels. Unmin/Undist, unmineralized/undisturbed soils; Min/Undist, mineralized/undisturbed soils; Min/Dist, mineralized/disturbed (waste-rock and tailings piles); (B), samples taken between shrub canopies (Min/Dist samples were also taken between shrub canopies); bdl, below detection limit; $\mathrm{SO} 4$, sulfate. 

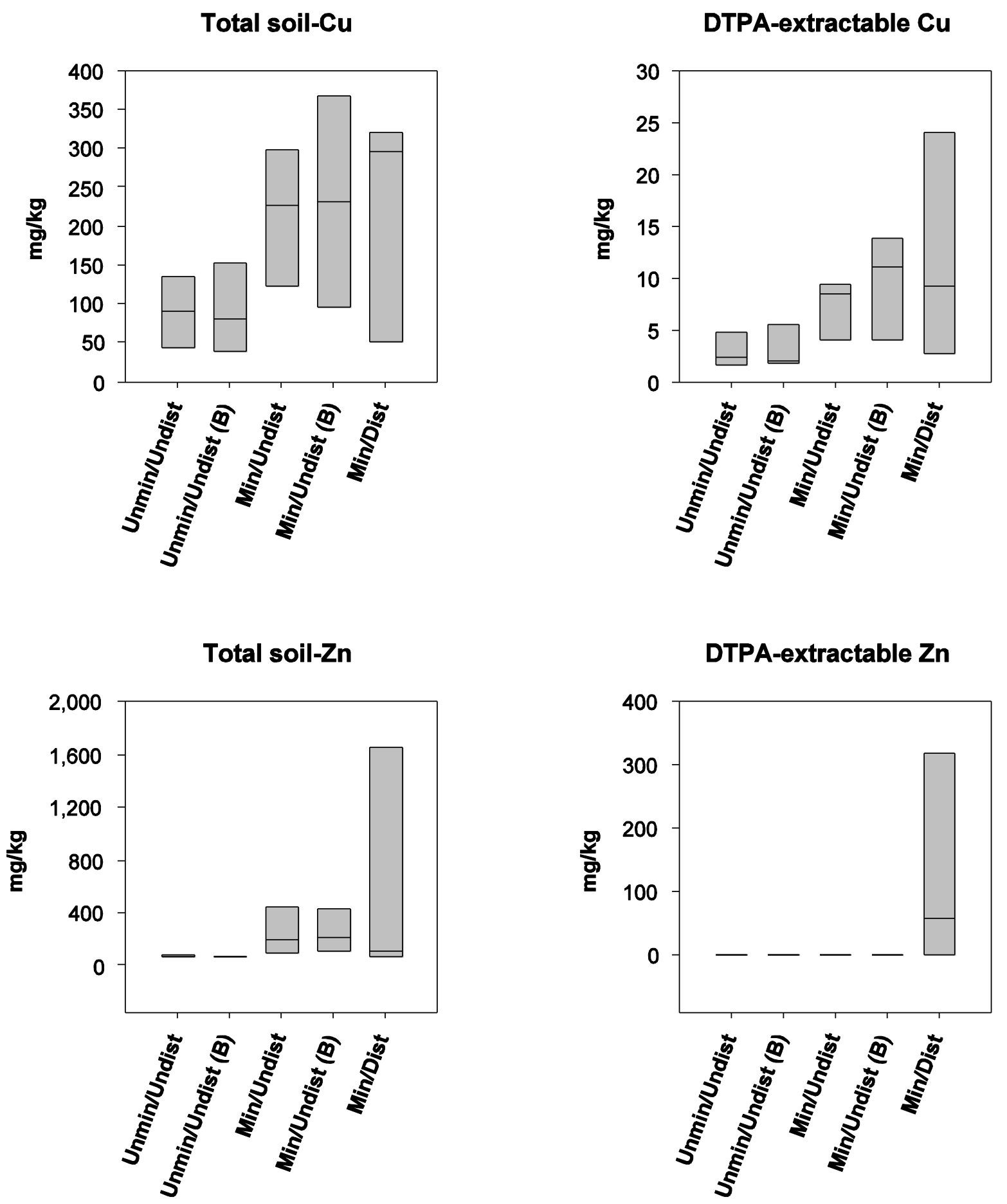

Figure 28. Buckingham study area, north-central, Nevada: Selected soil metal data (Total and DTPA-extractable $\mathrm{Cu}$ and $\mathrm{Zn}$ ) across the study-design levels. Unmin/Undist, unmineralized/undisturbed soils; Min/Undist, mineralized/undisturbed soils; Min/Dist, mineralized/disturbed (waste-rock and tailings piles); (B), samples taken between shrub canopies (Min/Dist samples were also taken between shrub canopies). 
Total Soil-As

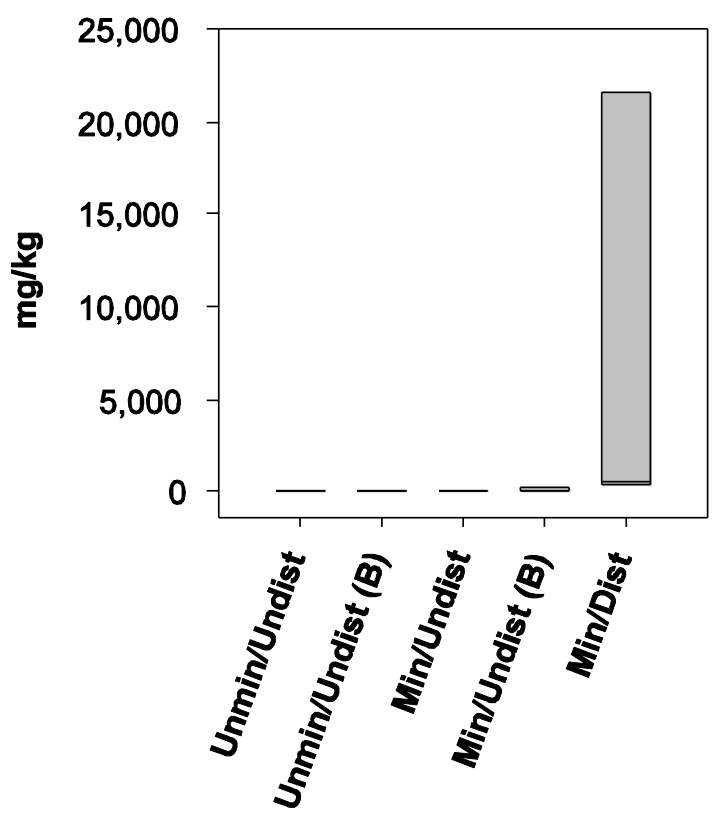

Total Soil-Pb

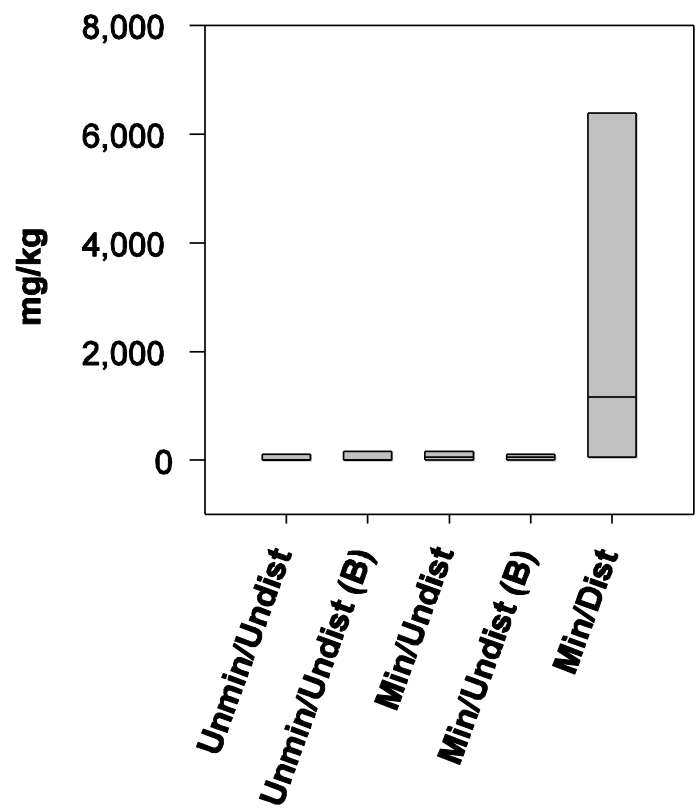

DTPA-extractable As

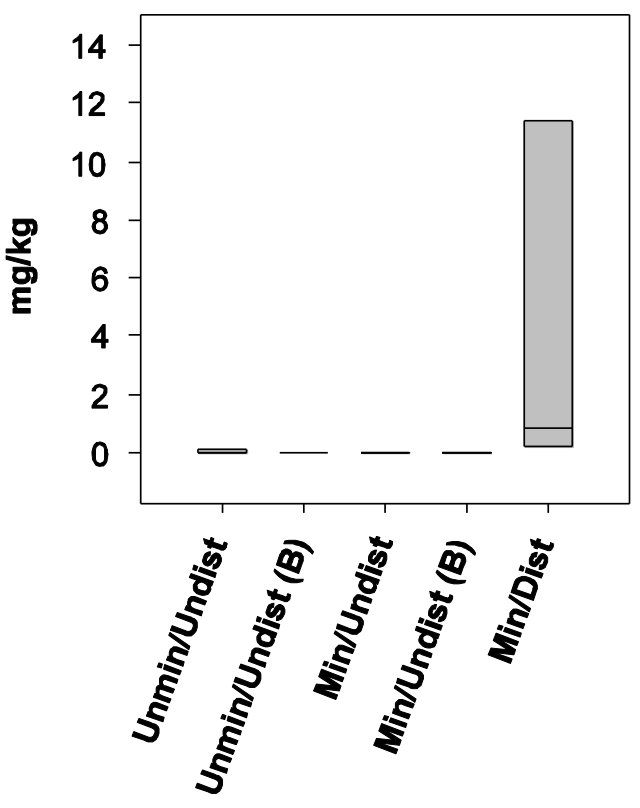

DTPA-extractable Pb

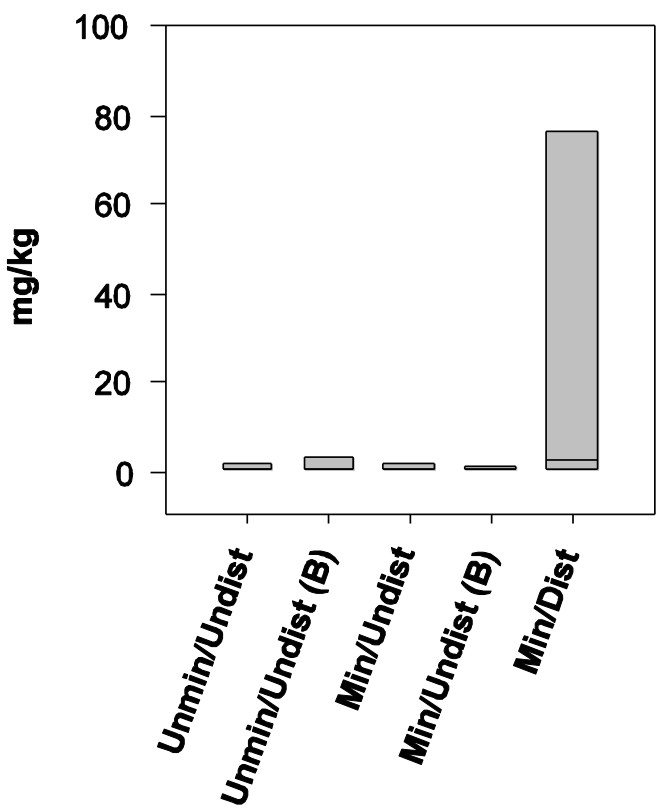

Figure 29. Buckingham study area, north-central, Nevada: Selected soil metal data (Total and DTPA-extractable As and $\mathrm{Pb}$ ) across the study-design levels. Unmin/Undist, unmineralized/undisturbed soils; Min/Undist, mineralized/undisturbed soils; Min/Dist, mineralized/disturbed (waste-rock and tailings piles); (B), samples taken between shrub canopies (Min/Dist samples were also taken between shrub canopies). 

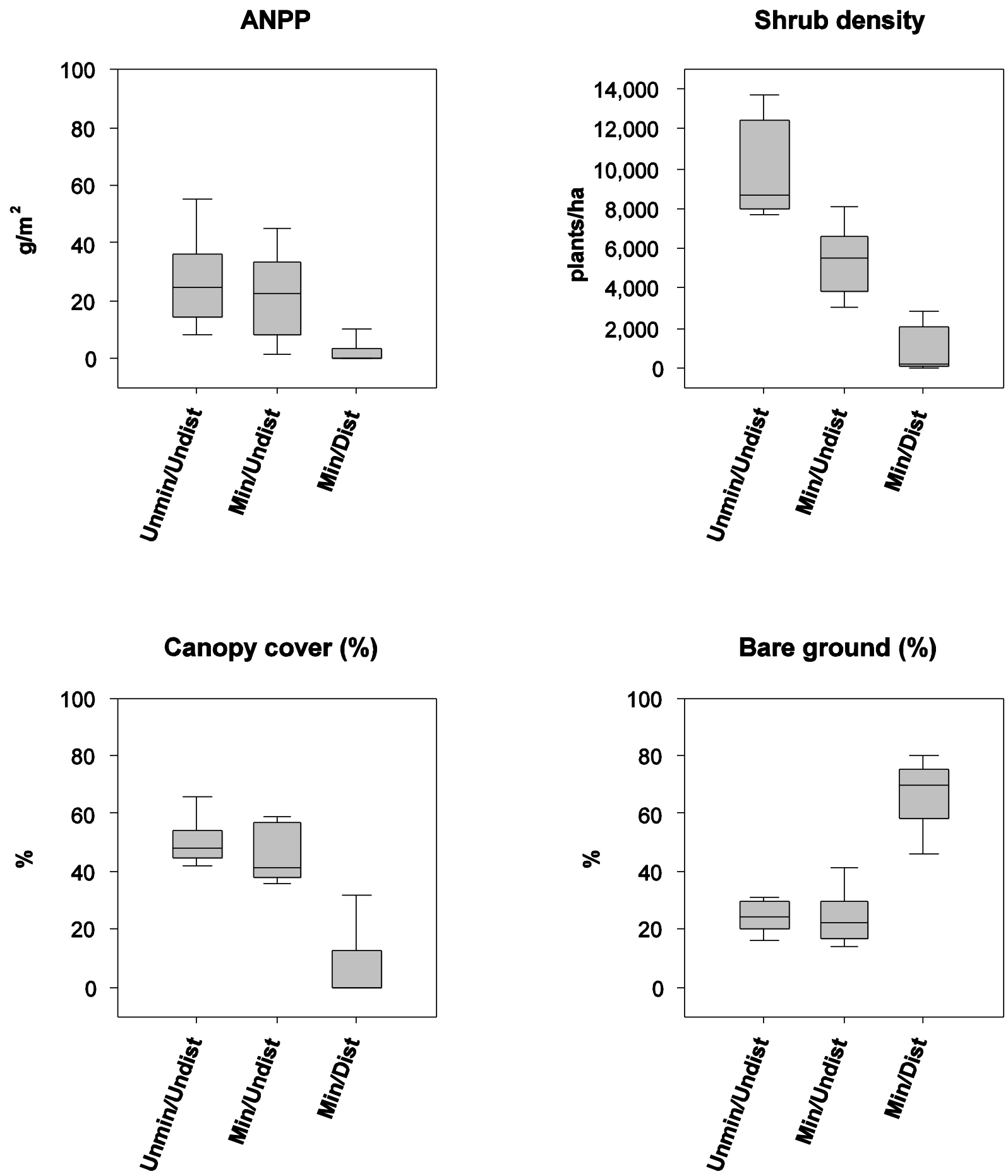

Figure 30. Buckingham study area, north-central, Nevada: Selected vegetation data (Aboveground net primary productivity (ANPP), Shrub density, Canopy cover, Bare ground) across the study-design levels. Unmin/Undist, unmineralized/undisturbed soils; Min/Undist, mineralized/undisturbed soils; Min/Dist, mineralized/disturbed (wasterock and tailings piles). 